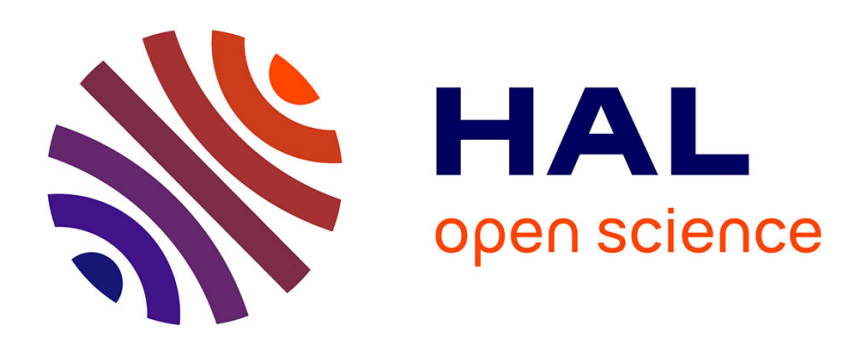

\title{
Modes of Deposit-Induced Accelerated Attack of MCrAlY Systems at $1100{ }^{\circ} \mathrm{C}$
}

Thomas Gheno, Brian Gleeson

\section{To cite this version:}

Thomas Gheno, Brian Gleeson. Modes of Deposit-Induced Accelerated Attack of MCrAlY Systems at $1100{ }^{\circ} \mathrm{C}$. Oxidation of Metals, 2017, 87 (1-2), pp.249-270. 10.1007/s11085-016-9669-1 . hal-01954754

\section{HAL Id: hal-01954754 \\ https://hal.science/hal-01954754}

Submitted on 13 Dec 2018

HAL is a multi-disciplinary open access archive for the deposit and dissemination of scientific research documents, whether they are published or not. The documents may come from teaching and research institutions in France or abroad, or from public or private research centers.
L'archive ouverte pluridisciplinaire HAL, est destinée au dépôt et à la diffusion de documents scientifiques de niveau recherche, publiés ou non, émanant des établissements d'enseignement et de recherche français ou étrangers, des laboratoires publics ou privés. 


\title{
Modes of deposit-induced accelerated attack of MCrAlY systems at $1100{ }^{\circ} \mathrm{C}$
}

\author{
Thomas Gheno* (ID) and Brian Gleeson \\ Department of Mechanical Engineering and Materials Science, \\ University of Pittsburgh, Pittsburgh PA 15261, USA \\ Email: thomas.gheno at gmail; bgleeson at pitt.edu
}

This is a post-peer-review, pre-copyedit version of an article published in Oxidation of Metals. The final version is available online at: https://doi.org/10.1007/s11085-016-9669-1

\begin{abstract}
The reaction of cast $\mathrm{NiCoCrAlY}$ alloys with oxide-sulfate deposits in $\mathrm{CO}_{2}-\mathrm{H}_{2} \mathrm{O}-\mathrm{O}_{2}$ was studied at $1100{ }^{\circ} \mathrm{C}$. The minimum $\mathrm{Al}$ concentration needed to form an external $\mathrm{Al}_{2} \mathrm{O}_{3}$ scale was increased compared with depositfree exposures, as $\mathrm{Al}_{2} \mathrm{O}_{3}$-forming compositions transitioned to internal $\mathrm{Al}_{2} \mathrm{O}_{3}$ and external $\mathrm{Cr}_{2} \mathrm{O}_{3}$ growth in the presence of certain deposits. Model deposits were used to investigate the role of each constituent in the complex reaction morphology observed with an industrial fly-ash. Two main modes of degradation were identified, which involved $\mathrm{Al}_{2} \mathrm{O}_{3}$ dissolution in molten $\mathrm{Na}$ silicate and solid-state $\mathrm{Al}_{2} \mathrm{O}_{3}$ reaction with $\mathrm{CaO}$. Both led to enhanced $\mathrm{Al}$ consumption and promoted non-selective oxidation. Additions of $\mathrm{Al}_{2} \mathrm{O}_{3}$ or $\mathrm{SiO}_{2}$ decreased the $\mathrm{CaO}$ reactivity due to the formation of aluminates or silicates, while $\mathrm{Na}_{2} \mathrm{SO}_{4}$, on the contrary, enhanced the degradation by providing rapid mass transport in the molten state, and reduced alloy/scale adherence. A systematic study of the role of phase fractions and phase compositions in the $\gamma-(\mathrm{Ni}, \mathrm{Co})+\beta-(\mathrm{Ni}, \mathrm{Co}) \mathrm{Al}$ metal system is reported, with the aim of providing guidance in coating design. In particular, high $\gamma$ fractions and $\mathrm{Cr}$ concentrations, which offer optimal hot corrosion resistance, were most susceptible to degradation by oxide-sulfate deposits.
\end{abstract}

Keywords MCrAlY coatings; Selective oxidation, Fly-ash; Silicate deposits

\section{Introduction}

Deposit-induced degradation concerns a variety of high-temperature processes, e.g., in aircraft, marine and land-based turbines, and in industrial boilers in general. Particulate matter ingested by an aircraft turbine via its air intake is generally described as calcium-magnesium alumino-silicate or CMAS. In marine engines, chlorides (e.g., $\mathrm{NaCl}, \mathrm{KCl}$ ) can combine with $\mathrm{SO}_{x}$ from the environment or produced by combustion of the kerosene to form sulfates (e.g., $\mathrm{Na}_{2} \mathrm{SO}_{4}, \mathrm{~K}_{2} \mathrm{SO}_{4}$ ). In waste or biomass incinerators, sulfur levels are usually low and alkali metals condense as chlorides. Integrated gasification combined cycle (IGCC) plants currently under development are designed to convert coal or a combination of coal and biomass into syngas, which then fuels a combustion turbine to generate electricity [1-3]. In addition to harsh gas environments $\left(\mathrm{CO}_{2}, \mathrm{H}_{2} \mathrm{O}, \mathrm{SO}_{2}\right)$, IGCC system turbine components are exposed to deposits of fly-ash which primarily contains $\mathrm{SiO}_{2}, \mathrm{Al}_{2} \mathrm{O}_{3}, \mathrm{CaO}, \mathrm{MgO}$ and $\mathrm{Fe}_{2} \mathrm{O}_{3}$ [4], but also $\mathrm{K}_{2} \mathrm{SO}_{4}$ and $\mathrm{Na}_{2} \mathrm{SO}_{4}$ as indicated above and $\mathrm{FeS}$ from the sulfidation of steel

\footnotetext{
${ }^{*}$ now at DEN-Service de la Corrosion et du Comportement des Matériaux dans leur Environnement, CEA, Université Paris-Saclay, 91191 Gif-sur-Yvette, France
} 


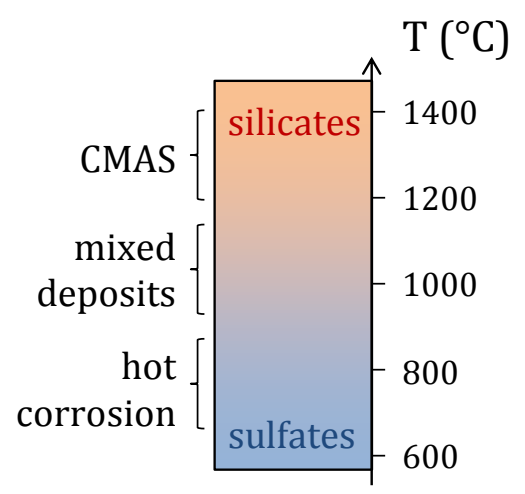

Figure 1: Schematic view of the temperature range and type of deposit relevant to the present work, in comparison with two typical modes of degradation, CMAS and hot corrosion.

components upstream [5]. The main source of particulate matter is the ambient air ingested by the turbine [6].

Particulate matter compositions vary widely depending on the fuel used and on the turbine location. Bituminous and anthracite coal, for example, tend to produce fly-ash rich in $\mathrm{SiO}_{2}$ and $\mathrm{Al}_{2} \mathrm{O}_{3}$, while fly-ash from subbituminous and lignite coals contain higher levels of $\mathrm{CaO}$ [7]. In addition, the nature of a deposit depends on the local temperature and gas composition. At high temperatures and low sulfur activities for example, alkali metals will tend to be present as silicates, while at lower temperatures and higher $p_{\mathrm{SO}_{3}}$, alkaline earth metals such as $\mathrm{Ca}$ or $\mathrm{Mg}$ might form sulfates rather than silicates.

Metal coatings applied to impart corrosion resistance to Ni-based structural components in gas turbines include nickel aluminides $\beta-\mathrm{NiAl}$ and $\mathrm{MCrAlY}(\mathrm{M}=\mathrm{Ni}, \mathrm{Co}$ or both), based on the $\mathrm{B} 2$ compound $\beta-(\mathrm{Ni}, \mathrm{Co}) \mathrm{Al}$ and the fcc-A1 solid solution $\gamma-(\mathrm{Ni}, \mathrm{Co})[8,9]$. Thermal barrier coatings (TBCs) are used on the hottest components, and include an yttria-stabilized zirconia (YSZ) ceramic topcoat for thermal insulation [10-14]. Since their inception, research on deposit-induced degradation of TBC systems has mostly focused on two aspects, CMAS and hot corrosion. At very high temperatures $\left(>1200{ }^{\circ} \mathrm{C}\right)$, CMAS deposits melt and infiltrate the YSZ, causing thermo-chemical and thermo-mechanical damage [4,15-18]. Accelerated corrosion of the bondcoat may occur if the YSZ topcoat is removed or otherwise allows access to condensed species. Ni- and Co-base materials are particularly susceptible to hot corrosion, a potentially severe form of attack at relatively low temperatures (700$900{ }^{\circ} \mathrm{C}$ ), where molten sulfates dissolve the thermally grown oxides and prevent the establishment of a protective scale [19-24].

Laboratory CMAS studies do not generally include alkali metal sulfates, because these rapidly volatilize at temperatures where the CMAS is molten $\left(>1200{ }^{\circ} \mathrm{C}\right)$. On the other hand, hot corrosion studies mostly do not consider oxides or silicates, because these do not melt at temperatures relevant to metal components (700$900{ }^{\circ} \mathrm{C}$ ). However, depending on the operating conditions, deposits may contain both oxides and sulfates, and continuously increasing service temperatures imply that bondcoats will be exposed to these mixed deposits in an intermediate temperature range $\left(900-1100{ }^{\circ} \mathrm{C}\right)$, where both solid and liquid phases may be of concern (Fig. 1). 
This paper presents part of a broader study of deposit-induced accelerated corrosion of MCrAlY coatings in conditions relevant to IGCC systems. Ref. [25] addressed the reaction with pure $\mathrm{CaO}$ deposits at $1100{ }^{\circ} \mathrm{C}$. The present paper aims at examining the modes of attack relevant to more complex and realistic oxide-sulfate deposits. In order to study the effect of coating microstructure in a wide composition range, a series of alloys were prepared to provide systematic variations of phase fractions and phase compositions. Cast versions were used in place of coatings. The effects of gas composition and temperature, as well as mechanistic aspects of the accelerated attack, are addressed in companion papers [26,27].

\section{Materials and experiments}

Three series of cast NiCoCrAlY alloys were used in this study. Nominal compositions are given in Table 1. First, a $\beta$-rich composition typical of bondcoats in plasmasprayed TBCs was made with two Y levels, 0.3 and 0.1 at. \% (all alloy compositions are given in at. \%). Alloys UT3 to UT8 all have $30 \mathrm{Co}$ and systematic variations of $\mathrm{Al}$ and $\mathrm{Cr}(12 / 16 \mathrm{Al}, 27 / 30 / 33 \mathrm{Cr})$. A third series of alloys was designed to obtain independent variations of phase fractions and phase compositions in the $\gamma-\beta$ field at $1100{ }^{\circ} \mathrm{C}$. Alloy UT11 has a high $\beta$ fraction, $f_{\beta}=63$ vol. $\%$, and a relatively low $\mathrm{Cr}$ concentration, 10 at. \%. Alloy UT14 was designed to have the same $f_{\beta}$ as UT4, but with the same phase compositions as UT11, that is, on the same tieline. In the same way, UT15 was designed to have the same $f_{\beta}$ as UT11, on the tie-line defined by UT4. Finally, UT12 and UT16 are the $\gamma$ and $\beta$ end-members of the tie-line defined by UT4, while UT13 and UT17 are the conjugate $\gamma$ and $\beta$ compositions for an equilibrated UT11. As shown in Fig. 2, this procedure provided two sets, each with four alloys on a particular tie-line, extending from single-phase $\gamma$ to single-phase $\beta$. The alloys also form four sets of two alloys, each with a constant phase fraction but different phase compositions. All phase equilibrium calculations were done for $T=1100{ }^{\circ} \mathrm{C}$, using the NIST database [28] in Thermo-Calc [29]. The later use of CRALDAD, a more recent database specifically developed for the Al-Co-Cr-Ni system [30,31], showed that the alloys were in fact slightly off the tie-lines; nevertheless, the principle of independently varying phase fractions and phase compositions is still qualitatively valid. For clarity of reading, the alloys will be referred to using their $\beta$ fraction (vol. \%) and $\mathrm{Cr}$ concentration (at. \%). For example, UT3 $\mathrm{Ni}-30 \mathrm{Co}-27 \mathrm{Cr}-12 \mathrm{Al}-0.1 \mathrm{Y}$ is abbreviated $13 \beta-27 \mathrm{Cr}$.

Ingots were made by argon-arc melting, followed by drop casting into $10 \mathrm{~mm}$ diameter rods, which were then homogenized in vacuum for $6 \mathrm{~h}$ at $1200{ }^{\circ} \mathrm{C}$ plus another $48 \mathrm{~h}$ at $1150{ }^{\circ} \mathrm{C}$. All processing was conducted at the Materials Preparation Center of the Ames Laboratory [32]. Specimens approximately $1 \mathrm{~mm}$ thick were cut from the heat-treated rods, ground using SiC paper to a P1200-grit finish, then degreased with detergent and ultrasonically cleaned in ethanol before exposure.

Microstructural characterization after further annealing at $1100{ }^{\circ} \mathrm{C}$ followed by air cooling confirmed the $\gamma-\beta$ phase constitution. Some alloys also precipitated $\sigma-\mathrm{CoCr}: 1,2$ and 22 vol. \% in $18 \beta-33 \mathrm{Cr}, 40 \beta-30 \mathrm{Cr}$ and $42 \beta-33 \mathrm{Cr}$, respectively, as measured by image analysis. A thorough characterization of phase equilibria in the $\mathrm{Al}-\mathrm{Co}-\mathrm{Cr}-\mathrm{Ni}$ system can be found in Ref. [30]. The alloys contained a small amount of yttrium-rich intermetallics $(\sim 0.1$ vol. $\%)$, the value being slightly smaller 
Table 1: Nominal composition of NiCoCrAlY alloys used in the present study (at. \%). A number of alloys prepared by MPC at Ames Laboratory [32] were sent for ICP-OES analysis to Evans Analytical Group [33]. Measured concentrations were found to be within 0.5 at. \% of nominal concentrations for $\mathrm{Ni}, \mathrm{Co}, \mathrm{Cr}, \mathrm{Al}$, and within 0.05 at. \% for Y. Volume fractions of $\beta, f_{\beta}$, were measured by image analysis after annealing at $1100{ }^{\circ} \mathrm{C}$ for alloys UT2 to UT7, and calculated using the NIST database [28] for alloys UT11 to UT17 (see explanations in text).

\begin{tabular}{|c|c|c|c|c|c|c|c|}
\hline \multirow[t]{2}{*}{ \# } & \multirow[t]{2}{*}{ Ref. } & \multicolumn{5}{|c|}{ Elemental concentration (at. \%) } & \multirow{2}{*}{$\begin{array}{c}f_{\beta} \text { at } 1100{ }^{\circ} \mathrm{C} \\
(\text { vol. } \%)\end{array}$} \\
\hline & & $\mathrm{Ni}$ & Co & $\mathrm{Cr}$ & $\mathrm{Al}$ & $\mathrm{Y}$ & \\
\hline UT1 & & 42 & 19 & 15 & 24 & 0.3 & \\
\hline UT2 & $57 \beta-15 \mathrm{Cr}$ & 42 & 19 & 15 & 24 & 0.1 & 57 \\
\hline UT3 & $13 \beta-27 \mathrm{Cr}$ & 31 & 30 & 27 & 12 & 0.1 & 13 \\
\hline UT4 & $16 \beta-30 \mathrm{Cr}$ & 28 & 30 & 30 & 12 & 0.1 & 16 \\
\hline UT5 & $18 \beta-33 \mathrm{Cr}$ & 25 & 30 & 33 & 12 & 0.1 & 18 \\
\hline UT6 & $34 \beta-27 \mathrm{Cr}$ & 27 & 30 & 27 & 16 & 0.1 & 34 \\
\hline UT7 & $40 \beta-30 \mathrm{Cr}$ & 24 & 30 & 30 & 16 & 0.1 & 40 \\
\hline UT8 & $42 \beta-33 \mathrm{Cr}$ & 21 & 30 & 33 & 16 & 0.1 & 42 \\
\hline UT11 & $63 \beta-10 \mathrm{Cr}$ & 47 & 19 & 10 & 24 & 0.1 & 63 \\
\hline UT12 & $0 \beta-35 \mathrm{Cr}$ & 25 & 33 & 35 & 7 & 0.1 & 0 \\
\hline UT13 & $0 \beta-19 \mathrm{Cr}$ & 42 & 28 & 19 & 11 & 0.1 & 0 \\
\hline UT14 & $17 \beta-16 \mathrm{Cr}$ & 44 & 26 & 16 & 14 & 0.1 & 17 \\
\hline UT15 & $63 \beta-18 \mathrm{Cr}$ & 36 & 21 & 18 & 25 & 0.1 & 63 \\
\hline UT16 & $100 \beta-8 \mathrm{Cr}$ & 43 & 15 & 8 & 34 & 0.1 & 100 \\
\hline UT17 & $100 \beta-5 \mathrm{Cr}$ & 49 & 14 & 5 & 32 & 0.1 & 100 \\
\hline
\end{tabular}

for $\gamma$-rich compositions.

Isothermal corrosion experiments were conducted at $1100{ }^{\circ} \mathrm{C}$ in flowing $\mathrm{CO}_{2}-$ $20 \mathrm{H}_{2} \mathrm{O}$ and $\mathrm{CO}_{2}-20 \mathrm{H}_{2} \mathrm{O}-1.6 \mathrm{O}_{2}$ (vol. \%) mixtures, using a horizontal tube furnace. Gas flow rates were set to $100 \mathrm{ml} / \mathrm{min}$, with a linear velocity of $2 \mathrm{~mm} / \mathrm{s}$ at reaction temperature, and a total pressure slightly over $1 \mathrm{~atm}$. To obtain a wet gas, $\mathrm{CO}_{2}$ or $\mathrm{CO}_{2}-\mathrm{O}_{2}$ was bubbled through demineralised water set at $62{ }^{\circ} \mathrm{C}$, thereby producing a mixture with slightly more than the desired 0.2 atm $\mathrm{H}_{2} \mathrm{O}$. The excess water vapor was subsequently condensed by cooling the wet gas in a distillation column at $60{ }^{\circ} \mathrm{C}$. Prior to a given experiment, the furnace was stabilized at $1100{ }^{\circ} \mathrm{C}$ with the specimens positioned in a cold zone of the reaction tube, and the gas allowed to flow for $2 \mathrm{~h}$. To start the experiment, the specimens were magnetically pushed into the hot zone.

Specimens were exposed to class $\mathrm{C}$ fly-ash deposit procured from a conventional coal-fired power plant (composition and source details in Table 2), as well as model deposits. The latter were prepared by grinding laboratory grade reagents using a mortar and pestle, and were given no heat treatment prior to corrosion testing. The powders were mixed with ethanol, and the resulting slurry was applied to one face of a given specimen using a dropper. The procedure was adjusted to produce approximately uniform $30 \pm 5 \mathrm{mg} / \mathrm{cm}^{2}$ deposits after evaporation of the ethanol. 


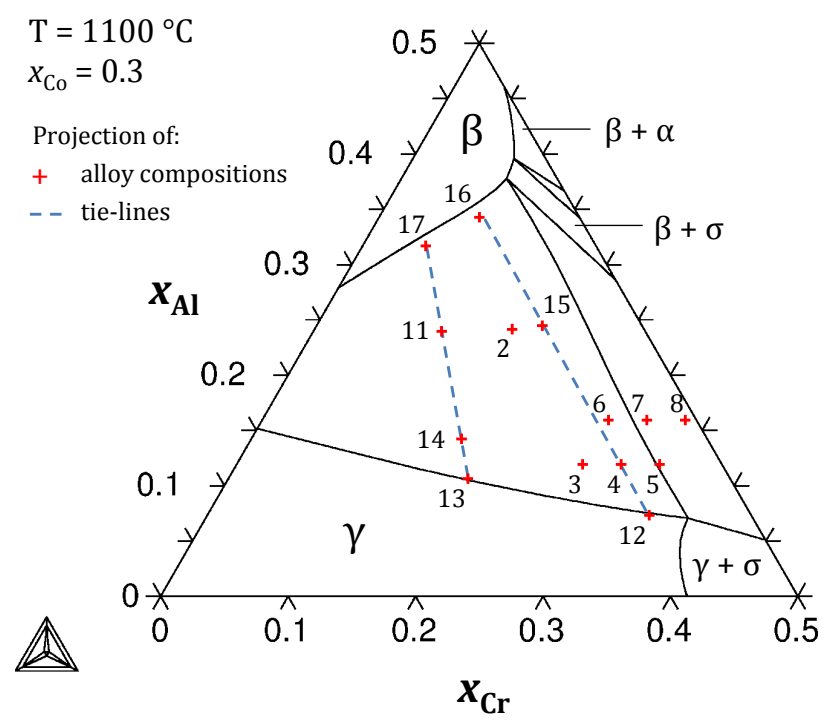

Figure 2: Alloy compositions (atom fractions) projected on an isothermal $\left(T=1100{ }^{\circ} \mathrm{C}\right)$, isoplethal $\left(x_{\mathrm{Co}}=0.3\right)$ section of the $\mathrm{Al}-\mathrm{Co}-\mathrm{Cr}-\mathrm{Ni}$ phase diagram calculated using the NIST database [28]. Alloys UT4 and UT11 to UT17 are along two tie-lines (see explanations in text). The projections of these tie-lines on the plane of constant $x_{\mathrm{Co}}=0.3$ are indicated by dashed lines.

Table 2: Composition of the fly-ash used in the present study, as reported on the supplier's certification report (wt. \%). The ash originated from the Scherer, GA coal-fired power plant and was purchased from Boral (San Antonio, TX). It is classified class C according to ASTM C618 and AASHTO M295 standards.

\begin{tabular}{lc}
\hline $\mathrm{SiO}_{2}$ & 25.3 \\
$\mathrm{Al}_{2} \mathrm{O}_{3}$ & 19.2 \\
$\mathrm{Fe}_{2} \mathrm{O}_{3}$ & 5.8 \\
$\mathrm{CaO}$ & 32.0 \\
$\mathrm{MgO}$ & 7.7 \\
$\mathrm{SO}_{3}$ & 3.2 \\
$\mathrm{Na}_{2} \mathrm{O}$ & 2.2 \\
$\mathrm{~K}_{2} \mathrm{O}$ & 0.4 \\
\hline
\end{tabular}

The phase constitution of the model mixtures was also studied by annealing in alumina crucibles with no alloy specimen.

After exposure, reaction products were examined by X-ray diffraction (XRD) using a Bruker D8 instrument with $\mathrm{Cu}$ radiation $\left(K_{\alpha 1}=1.54 \AA\right)$ and Panalytical HighScore Plus processing software. Metallographic cross-sections were first prepared using water-free cutting fluids and polishing suspensions to retain any water-soluble products such as $\mathrm{Na}_{2} \mathrm{SO}_{4}$. Preliminary observations showed the sulfate rapidly reacted or evaporated, and subsequent metallographic preparation was done with water-base products. Specimens were characterized by SEM with a JEOL JSM 6510, and in selected cases by electron probe micro-analysis (EPMA) using a JEOL JXA 8530F. Measured intensities were processed via a built-in ZAF calibration procedure using pure metals as standards. 


\section{Results}

\subsection{Oxidation with no deposit}

All alloys (Table 1) were exposed to $\mathrm{CO}_{2}-20 \mathrm{H}_{2} \mathrm{O}-1.6 \mathrm{O}_{2}$ with no deposit for $50 \mathrm{~h}$ and found to form external $\mathrm{Al}_{2} \mathrm{O}_{3}$ scales. Small amounts of $\mathrm{Cr}$, Co or Ni oxide were present in the outermost part of the scales, depending on alloy composition. The alloy with lowest $\mathrm{Al}$ concentration, $0 \beta-35 \mathrm{Cr}$, was a borderline $\mathrm{Al}_{2} \mathrm{O}_{3}$-former, in that it occasionally formed internal $\mathrm{Al}_{2} \mathrm{O}_{3}$ (and external $\mathrm{Cr}_{2} \mathrm{O}_{3}$ ) on the specimen edges.

\subsection{Exposure to class $\mathrm{C}$ fly-ash}

Alloys $57 \beta-15 \mathrm{Cr}, 13 \beta-27 \mathrm{Cr}, 16 \beta-30 \mathrm{Cr}, 18 \beta-33 \mathrm{Cr}, 34 \beta-27 \mathrm{Cr}, 40 \beta-30 \mathrm{Cr}$ and $42 \beta-$ $33 \mathrm{Cr}$ were exposed $50 \mathrm{~h}$ to the fly-ash in $\mathrm{CO}_{2}-20 \mathrm{H}_{2} \mathrm{O}$. As a general observation, $\beta$-rich alloys were immune to the ash, growing external $\mathrm{Al}_{2} \mathrm{O}_{3}$ as they did in the absence of a deposit, while $\gamma$-rich alloys were susceptible to a localized type of degradation (Fig. 3). In the latter case the reaction morphology was complex and non-uniform. The attack varied in extent but was of a similar nature for the different alloys. In some regions, the alloys formed an external $\mathrm{Al}_{2} \mathrm{O}_{3}$ layer covered by oxides of variable composition, ranging from that of the applied ash (with little $\mathrm{Cr}$, Co or $\mathrm{Ni}$ ) to $\mathrm{Cr}_{2} \mathrm{O}_{3}$. Other regions showed a more significant metal loss, as the corrosion product included an inner part of mixed Al-rich, Cr-rich and ( $\mathrm{Co}, \mathrm{Ni})$-rich oxides. Even then, a continuous $\mathrm{Al}_{2} \mathrm{O}_{3}$ layer was almost always present at the base of the scale (Fig. 3c). Photo-stimulated luminescence spectroscopy, which allows $\mathrm{Al}_{2} \mathrm{O}_{3}$ polymorphs to be distinguished [34], showed this oxide to be $\alpha-\mathrm{Al}_{2} \mathrm{O}_{3}$. In these regions, the outer part of the corrosion product was a mixed, but mostly Cr-rich, oxide. The concentration of alloy elements in the outer part showed local variations, and generally decreased with increasing distance from the specimen surface.

Given the varied nature of the corrosion products, no attempt was made at quantifying the metal loss. Qualitatively, the severity of the attack decreased with increasing $\mathrm{Al}$ concentration, and therefore $\beta$ fraction, in the alloy; higher $\mathrm{Cr}$ appeared to make the attack more severe, but this was less marked.

The effect of Y concentration was tested using two versions of alloy $57 \beta-15 \mathrm{Cr}$, with 0.3 and 0.1 at. $\%$ Y. In the absence of a deposit, both versions formed YAl-O precipitates within the $\mathrm{Al}_{2} \mathrm{O}_{3}$ scale and intruding into the alloy. These were more numerous, larger and deeper in the $0.3 \mathrm{Y}$ version. With the ash, while the $0.1 \mathrm{Y}$ version formed external $\mathrm{Al}_{2} \mathrm{O}_{3}$ (Fig. 3a), the $0.3 \mathrm{Y}$ version was susceptible to localized attack. As shown in Fig. 4, large $\mathrm{Y}-\mathrm{Al}-\mathrm{O}$ intrusions were found to disrupt the $\mathrm{Al}_{2} \mathrm{O}_{3}$ scale and to act as initiation sites for reaction of the alloy with the ash. This appeared to be short-lived, however, as a continuous $\mathrm{Al}_{2} \mathrm{O}_{3}$ layer was usually present at the base of the intrusions. In one specimen, zones of severe degradation (> 15 um deep metal loss) were observed, but corrosion tests conducted for several durations showed these to be isolated events.

\subsection{Exposure to model deposits}

In order to investigate the role of the deposit constituents in the corrosion process, further testing was conducted using model deposits. Fig. 5 shows $\gamma$-rich alloys after exposure to a model mixture with the same composition as the fly-ash used 

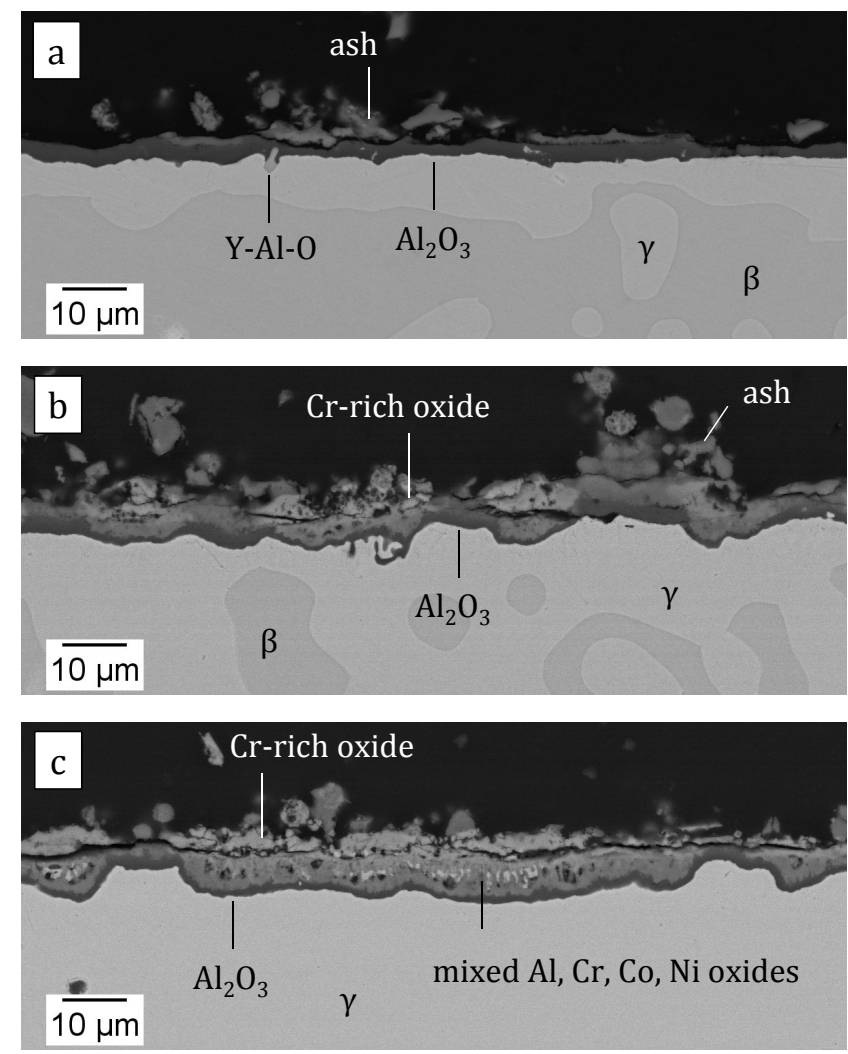

Figure 3: Corrosion products observed after $50 \mathrm{~h}$ exposure to fly-ash (composition in Table 2) in $\mathrm{CO}_{2}-20 \mathrm{H}_{2} \mathrm{O}$ at $1100{ }^{\circ} \mathrm{C}$. Alloys (a) $57 \beta-15 \mathrm{Cr}$; (b) $40 \beta-30 \mathrm{Cr}$; (c) $16 \beta-30 \mathrm{Cr}$. The extent of degradation increases with decreasing alloy $\beta$ fraction.

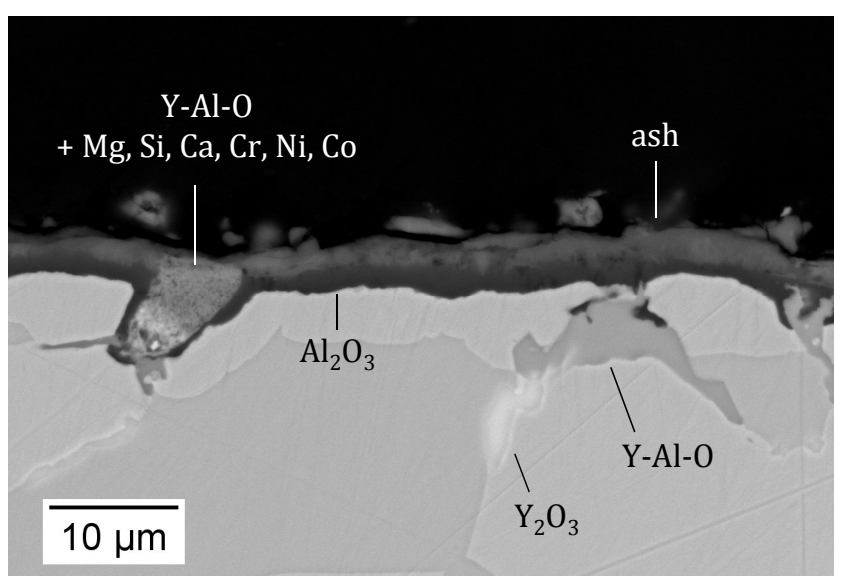

Figure 4: Alloy $57 \beta-15 \mathrm{Cr}$ with 0.3 at. $\% \mathrm{Y}$ after $50 \mathrm{~h}$ exposure to fly-ash (Table 2) in $\mathrm{CO}_{2}-20 \mathrm{H}_{2} \mathrm{O}$ at $1100{ }^{\circ} \mathrm{C}$. Where a large $\mathrm{Y}-\mathrm{Al}-\mathrm{O}$ intrusion was present, a mixed corrosion product formed which contained elements from both the ash and the alloy. 

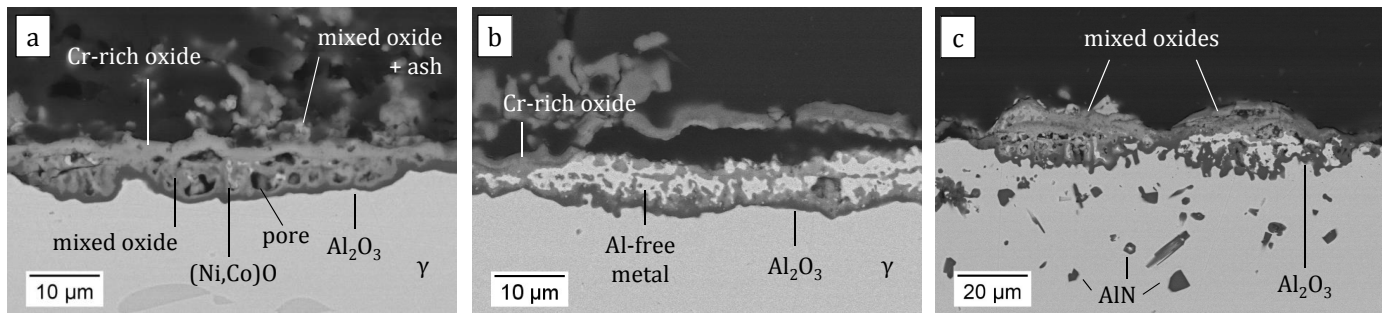

Figure 5: Local variations in corrosion product morphology observed on $\gamma$-rich alloys exposed to a model deposit with the same composition as the fly-ash (Table 2), $50 \mathrm{~h}$ at $1100{ }^{\circ} \mathrm{C}$. The zone above the secondary $\mathrm{Al}_{2} \mathrm{O}_{3}$ layer is either (a) fully oxidized (alloy $16 \beta-$ $30 \mathrm{Cr}$ in $\mathrm{CO}_{2}-20 \mathrm{H}_{2} \mathrm{O}$ ) or (b) contains a mixture of Al-rich oxide and Al-free metal (alloy $13 \beta-27 \mathrm{Cr}$ in $\mathrm{CO}_{2}-20 \mathrm{H}_{2} \mathrm{O}$ ). These two morphologies are occasionally observed side to side on a given specimen, as shown in (c) (alloy $16 \beta-30 \mathrm{Cr}$ in dry air).

Table 3: Composition of the model deposits used in this study (wt. \%).

\begin{tabular}{lcccc}
\hline Ref. & $\mathrm{SiO}_{2}$ & $\mathrm{Al}_{2} \mathrm{O}_{3}$ & $\mathrm{CaO}$ & $\mathrm{Na}_{2} \mathrm{SO}_{4}$ \\
\hline $\mathrm{Al}_{2} \mathrm{O}_{3}-\mathrm{CaO}$ & & 60 & 40 & \\
$\mathrm{SiO}_{2}-\mathrm{CaO}$ & 60 & & 40 & \\
$\mathrm{CaO}-\mathrm{Na}_{2} \mathrm{SO}_{4}$ & & & 90 & 10 \\
$\mathrm{Al}_{2} \mathrm{O}_{3}-\mathrm{Na}_{2} \mathrm{SO}_{4}$ & & 90 & & 10 \\
$\mathrm{SiO}_{2}-\mathrm{Na}_{2} \mathrm{SO}_{4}$ & 90 & & & 10 \\
$\mathrm{Al}_{2} \mathrm{O}_{3}-\mathrm{CaO}-\mathrm{Na}_{2} \mathrm{SO}_{4}$ & & 50 & 40 & 10 \\
$\mathrm{SiO}_{2}-\mathrm{CaO}-\mathrm{Na}_{2} \mathrm{SO}_{4}$ & 50 & & 40 & 10 \\
$\mathrm{SiO}_{2}-\mathrm{Al}_{2} \mathrm{O}_{3}-\mathrm{CaO}-\mathrm{Na}_{2} \mathrm{SO}_{4}$ & 25 & 25 & 40 & 10 \\
\hline
\end{tabular}

previously (Table 2). The reaction morphology was also non-uniform. In some regions (Fig. 5a), it was identical to that observed with the fly-ash. In other regions (Fig. 5b), the inner part consisted of a mixture of Al-rich oxide and Al-free metal. As discussed later, these are stages of the same process: the fully-oxidized type is simply a more advanced state of the internally-oxidized type. The two morphologies were occasionally observed side-by-side on a given specimen, as shown in Fig. 5c. The similarity in results obtained with the fly-ash and the model deposit validates the use of the latter to study the relevant reaction mechanisms.

A first screening of alloy-oxide interactions was done by reacting a $\gamma$-rich alloy, $18 \beta-33 \mathrm{Cr}$, and a $\beta$-rich alloy, $57 \beta-15 \mathrm{Cr}, 50 \mathrm{~h}$ in dry air with the following individual oxide deposits: $\mathrm{SiO}_{2}, \mathrm{Al}_{2} \mathrm{O}_{3}, \mathrm{Fe}_{2} \mathrm{O}_{3}, \mathrm{CaO}$ and $\mathrm{MgO}$. When contacted with $\mathrm{SiO}_{2}$, $\mathrm{Al}_{2} \mathrm{O}_{3}$ and $\mathrm{Fe}_{2} \mathrm{O}_{3}$, both alloys formed an $\mathrm{Al}_{2} \mathrm{O}_{3}$ scale, not significantly different from those grown in the absence of a deposit. Reaction with $\mathrm{CaO}$ and $\mathrm{MgO}$ produced $\mathrm{Ca}$ and $\mathrm{Mg}$ aluminates in addition to $\mathrm{Al}_{2} \mathrm{O}_{3}$; with $\mathrm{CaO}$, the $\gamma$-rich alloy also formed a liquid $\mathrm{Ca}$ chromate before passivating [25]. Based on these results, model deposits were designed as combinations of three types of constituents: $\mathrm{Al}_{2} \mathrm{O}_{3}$ or $\mathrm{SiO}_{2}$ as a relatively acidic oxide; $\mathrm{CaO}$ as a basic oxide; $\mathrm{Na}_{2} \mathrm{SO}_{4}$ as an alkali metal sulfate. Corrosion tests using the deposit compositions given in Table 3 were conducted for $50 \mathrm{~h}$ in $\mathrm{CO}_{2}-20 \mathrm{H}_{2} \mathrm{O}-1.6 \mathrm{O}_{2}$ on selected $\gamma$-rich alloys. The following focuses on alloys $13 \beta-27 \mathrm{Cr}$ and $0 \beta-35 \mathrm{Cr}$. 

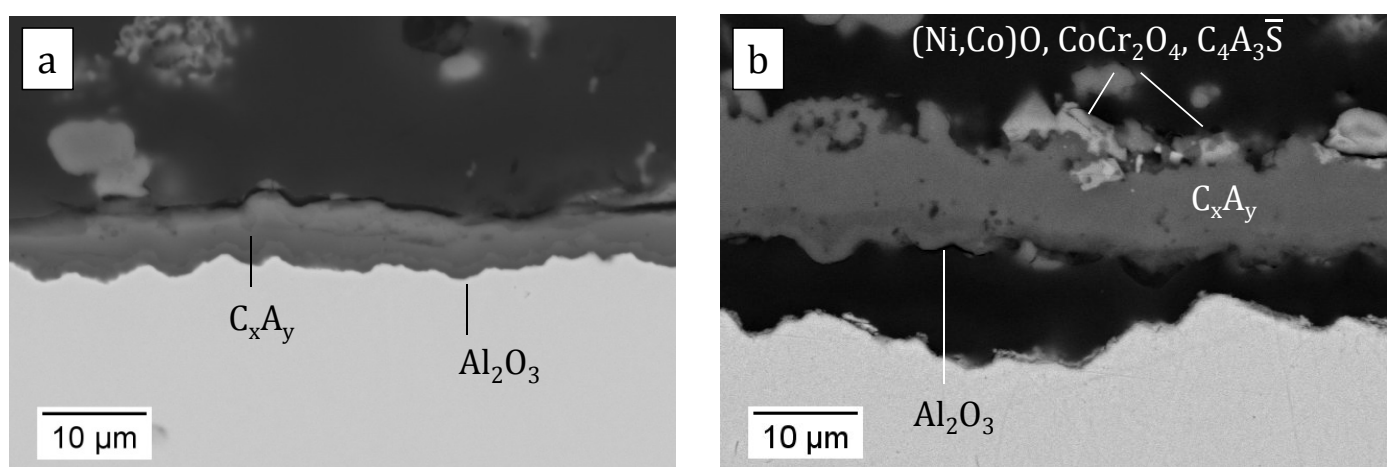

Figure 6: Corrosion products observed on alloy $13 \beta-27 \mathrm{Cr}$ after $50 \mathrm{~h}$ reaction in $\mathrm{CO}_{2}-$ $20 \mathrm{H}_{2} \mathrm{O}-1.6 \mathrm{O}_{2}$ at $1100{ }^{\circ} \mathrm{C}$ with (a) $\mathrm{Al}_{2} \mathrm{O}_{3}-40 \mathrm{CaO}$; (b) $\mathrm{Al}_{2} \mathrm{O}_{3}-40 \mathrm{CaO}-10 \mathrm{Na}_{2} \mathrm{SO}_{4}$. Mixed compound notation: C: $\mathrm{CaO} ; \mathrm{A}: \mathrm{Al}_{2} \mathrm{O}_{3} ; \overline{\mathrm{S}}: \mathrm{SO}_{3}$.

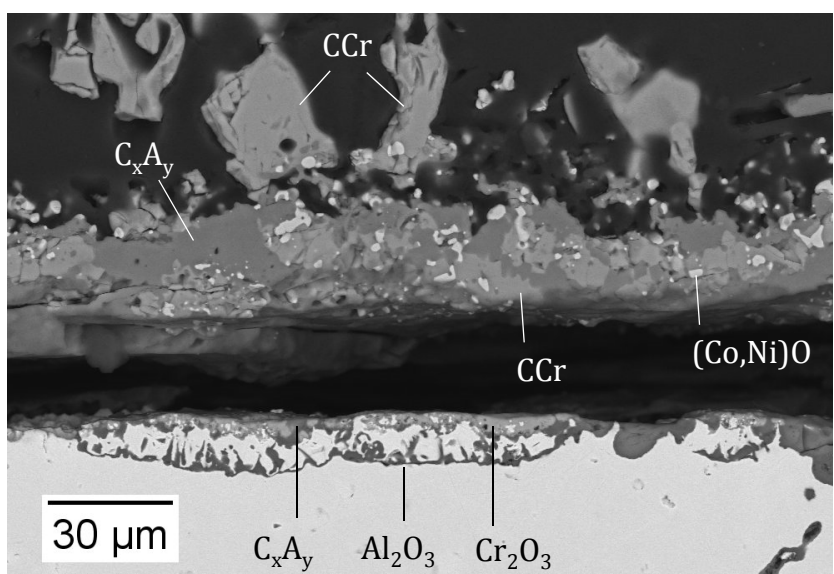

Figure 7: Corrosion products observed on alloy $13 \beta-27 \mathrm{Cr}$ after $50 \mathrm{~h}$ reaction in $\mathrm{CO}_{2}{ }^{-}$ $20 \mathrm{H}_{2} \mathrm{O}-1.6 \mathrm{O}_{2}$ at $1100{ }^{\circ} \mathrm{C}$ with $\mathrm{CaO}-10 \mathrm{Na}_{2} \mathrm{SO}_{4}$. Mixed compound notation: $\mathrm{C}$ : $\mathrm{CaO} ; \mathrm{A}$ : $\mathrm{Al}_{2} \mathrm{O}_{3} ; \mathrm{Cr}: \mathrm{Cr}_{2} \mathrm{O}_{3}$.

\section{$3.4 \quad 13 \beta-27 \mathrm{Cr}(\mathrm{Ni}-30 \mathrm{Co}-27 \mathrm{Cr}-12 \mathrm{Al}-0.1 \mathrm{Y})$}

Upon reaction with an $\mathrm{Al}_{2} \mathrm{O}_{3}-\mathrm{CaO}$ deposit, alloy $13 \beta-27 \mathrm{Cr}$ formed a scale of $\mathrm{Ca}$ aluminates (denoted $\mathrm{C}_{x} \mathrm{~A}_{y}$ ) and $\mathrm{Al}_{2} \mathrm{O}_{3}$ (Fig. 6a). Little Ca chromate (denoted $\mathrm{CCr}$ ) was observed. The deposit consisted of $\mathrm{C}_{x} \mathrm{~A}_{y}$ and some untransformed $\mathrm{Al}_{2} \mathrm{O}_{3}$ and $\mathrm{CaO}$. Adding $\mathrm{Na}_{2} \mathrm{SO}_{4}$ to $\mathrm{Al}_{2} \mathrm{O}_{3}-\mathrm{CaO}$ resulted in a thicker $\mathrm{C}_{x} \mathrm{~A}_{y}$ scale, with more transient oxides at its surface, i.e., $(\mathrm{Ni}, \mathrm{Co}) \mathrm{O}, \mathrm{CoCr}_{2} \mathrm{O}_{4}$, and calcium sulfo-aluminate $\mathrm{C}_{4} \mathrm{~A}_{3} \overline{\mathrm{S}}$ as shown in Fig. $6 \mathrm{~b}$. The scale had poor adherence to the alloy. Exposure to $\mathrm{CaO}-\mathrm{Na}_{2} \mathrm{SO}_{4}$ produced similar results, but the chromate was formed in greater quantity, and while an external $\mathrm{C}_{x} \mathrm{~A}_{y}-\mathrm{Al}_{2} \mathrm{O}_{3}$ scale developed in some regions, in others $\mathrm{C}_{x} \mathrm{~A}_{y}$ was embedded in $\mathrm{CCr}$ and $\mathrm{Al}$ oxidized internally (Fig. 7). The scale was mostly detached from the alloy. Exposure to $\mathrm{Al}_{2} \mathrm{O}_{3}-\mathrm{Na}_{2} \mathrm{SO}_{4}$ produced external $\mathrm{Al}_{2} \mathrm{O}_{3}$, also with poor adherence.

Reaction with $\mathrm{SiO}_{2}-\mathrm{CaO}$ produced a $\mathrm{C}_{x} \mathrm{~A}_{y}-\mathrm{Al}_{2} \mathrm{O}_{3}$ scale, with some $\mathrm{CCr}$, mixed Co-Ni-Cr oxide, and Ca alumino-silicate (Fig. 8). Calcium silicates also formed in the deposit. In contrast to $\mathrm{Na}_{2} \mathrm{O}-\mathrm{Al}_{2} \mathrm{O}_{3}$, the $\mathrm{Na}_{2} \mathrm{O}-\mathrm{SiO}_{2}$ system has a large liquid region at $1100{ }^{\circ} \mathrm{C}$ [35], and indeed, when mixed with $\mathrm{SiO}_{2}, \mathrm{Na}_{2} \mathrm{SO}_{4}$ reacted to form 


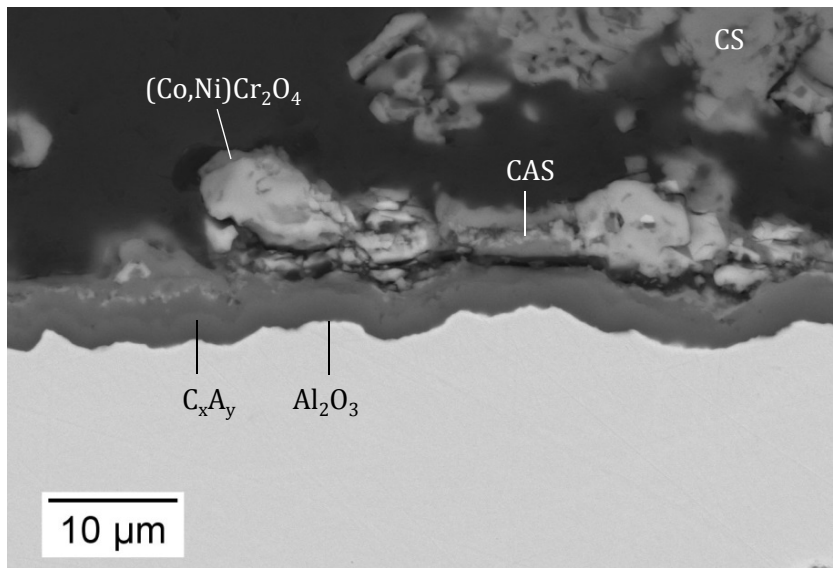

Figure 8: Corrosion products observed on alloy $13 \beta-27 \mathrm{Cr}$ after $50 \mathrm{~h}$ reaction in $\mathrm{CO}_{2}-$ $20 \mathrm{H}_{2} \mathrm{O}-1.6 \mathrm{O}_{2}$ at $1100{ }^{\circ} \mathrm{C}$ with $\mathrm{SiO}_{2}-40 \mathrm{CaO}$. Mixed compound notation: C: CaO; A: $\mathrm{Al}_{2} \mathrm{O}_{3}$; S: $\mathrm{SiO}_{2}$.

a molten $\mathrm{Na}$ silicate (denoted NS) on the specimen. The solubility of $\mathrm{Al}_{2} \mathrm{O}_{3}$ in this liquid is large [35], and indeed large amounts of $\mathrm{Al}(\sim 10$ at. \%) were found by SEM-EDS in the silicate near the specimen surface. The alloy mainly formed an external $\mathrm{Al}_{2} \mathrm{O}_{3}$ scale; in some locations, however, $\mathrm{Al}_{2} \mathrm{O}_{3}$ intrusions and external $\mathrm{Cr}_{2} \mathrm{O}_{3}$ were observed instead, as shown in Fig. 9a. Chromium was then found in the silicate, but mostly in the form of precipitated $\mathrm{Cr}_{2} \mathrm{O}_{3}$ - the concentration of dissolved $\mathrm{Cr}$ was about $0.5-1$ at. \%. The $\mathrm{Al}_{2} \mathrm{O}_{3}$ intrusions depth and $\mathrm{Cr}_{2} \mathrm{O}_{3}$ layer thickness were variable but generally limited to a few $\mu \mathrm{m}$.

With the $\mathrm{SiO}_{2}-\mathrm{CaO}-\mathrm{Na}_{2} \mathrm{SO}_{4}$ mixture, the bulk of the deposit consisted of $\mathrm{SiO}_{2}$ and $\mathrm{CaSiO}_{3}$, while liquid $\mathrm{Na}_{2} \mathrm{O}-\mathrm{CaO}-\mathrm{SiO}_{2}$ formed in contact with the specimen. The molten silicate also dissolved significant $\mathrm{Al}_{2} \mathrm{O}_{3}$. The alloy locally underwent internal oxidation (Fig. 9b). Some variability was observed in the morphology of these regions, as the reaction product above the internal $\mathrm{Al}_{2} \mathrm{O}_{3}$ consisted of either $\mathrm{C}_{x} \mathrm{~A}_{y}$ layers, typical of reaction with $\mathrm{CaO}$, or of $\mathrm{Cr}_{2} \mathrm{O}_{3}$ embedded in $\mathrm{Na}_{2} \mathrm{O}-\mathrm{CaO}-$ $\mathrm{Al}_{2} \mathrm{O}_{3}-\mathrm{SiO}_{2}$, similar to what was observed with $\mathrm{SiO}_{2}-\mathrm{Na}_{2} \mathrm{SO}_{4}$.

Finally, reaction with a $\mathrm{SiO}_{2}-\mathrm{Al}_{2} \mathrm{O}_{3}-\mathrm{CaO}-\mathrm{Na}_{2} \mathrm{SO}_{4}$ deposit resulted in almost uniform internal $\mathrm{Al}_{2} \mathrm{O}_{3}$ with external $\mathrm{Cr}_{2} \mathrm{O}_{3}$ (Fig. 9c). A continuous $\mathrm{Al}_{2} \mathrm{O}_{3}$ layer was found at the internal oxidation front. The deposit in contact with the specimen surface consisted of mixed alumino-silicate of varying composition. This reaction morphology resembled that observed with the fly-ash, shown in Fig. 5b.

\section{$3.50 \beta-35 \mathrm{Cr}(\mathrm{Ni}-33 \mathrm{Co}-35 \mathrm{Cr}-7 \mathrm{Al}-0.1 \mathrm{Y})$}

Reaction of alloy $0 \beta-35 \mathrm{Cr}$ with all tested deposits resulted in internal oxidation of $\mathrm{Al}$, albeit with differences depending on deposit composition. Exposure to $\mathrm{Al}_{2} \mathrm{O}_{3}-\mathrm{CaO}$ led to uniform, relatively deep internal oxidation of $\mathrm{Al}$ and thick external $\mathrm{Cr}_{2} \mathrm{O}_{3}$ (Fig. 10a). A continuous $\mathrm{Al}_{2} \mathrm{O}_{3}$ layer was present at the reaction front. Adding $\mathrm{Na}_{2} \mathrm{SO}_{4}$ to $\mathrm{Al}_{2} \mathrm{O}_{3}-\mathrm{CaO}$ led to a similar reaction morphology, although the depth of internal oxidation was locally reduced, and in some regions an external $\mathrm{Al}_{2} \mathrm{O}_{3}$ scale was present (Fig. 10b). Mixed $\mathrm{Ca}-\mathrm{Cr}$ aluminate and $\mathrm{CCr}$ formed near the specimen surface. 

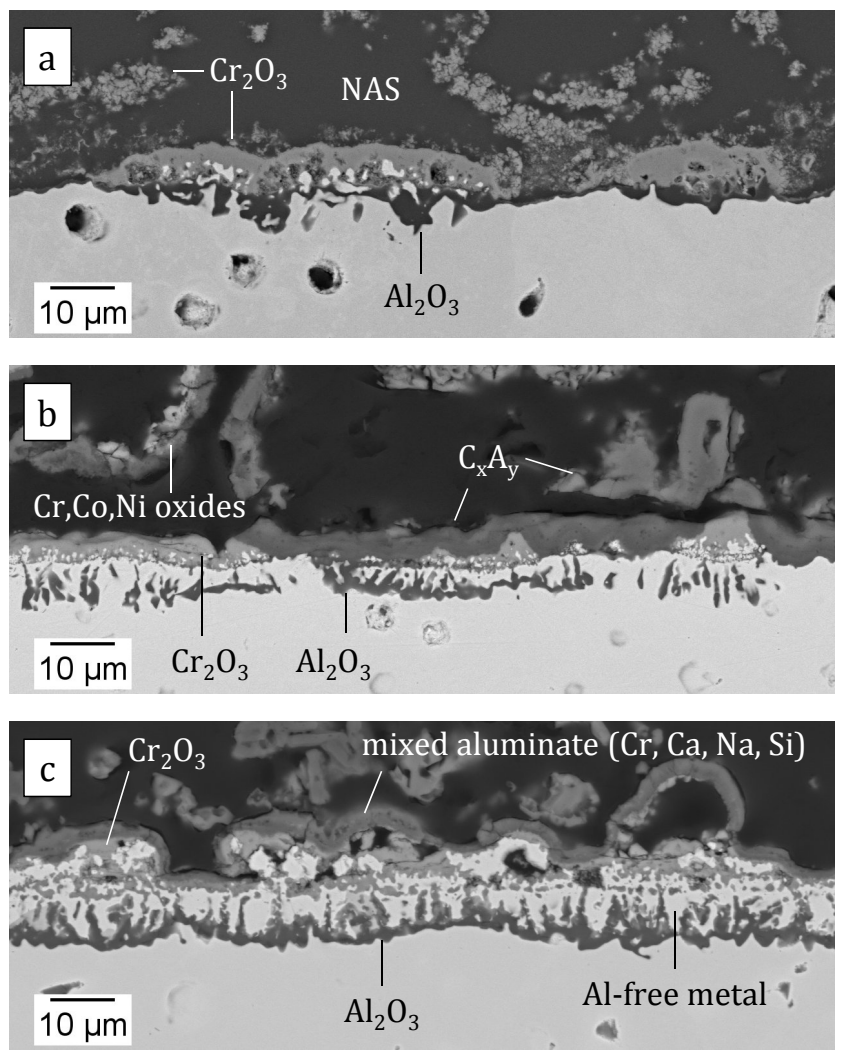

Figure 9: Corrosion products observed on alloy $13 \beta-27 \mathrm{Cr}$ after $50 \mathrm{~h}$ reaction in $\mathrm{CO}_{2}-$ $20 \mathrm{H}_{2} \mathrm{O}-1.6 \mathrm{O}_{2}$ at $1100{ }^{\circ} \mathrm{C}$ with (a) $\mathrm{SiO}_{2}-10 \mathrm{Na}_{2} \mathrm{SO}_{4}$; (b) $\mathrm{SiO}_{2}-40 \mathrm{CaO}-10 \mathrm{Na}_{2} \mathrm{SO}_{4}$; (c) $\mathrm{SiO}_{2}-$ $25 \mathrm{Al}_{2} \mathrm{O}_{3}-40 \mathrm{CaO}-10 \mathrm{Na}_{2} \mathrm{SO}_{4}$. Mixed compound notation: C: $\mathrm{CaO} ; \mathrm{A}: \mathrm{Al}_{2} \mathrm{O}_{3} ; \mathrm{N}: \mathrm{Na}_{2} \mathrm{O} ; \mathrm{S}$ : $\mathrm{SiO}_{2}$.

Exposure to $\mathrm{SiO}_{2}-\mathrm{CaO}$ resulted in a reaction morphology similar to that observed with $\mathrm{Al}_{2} \mathrm{O}_{3}-\mathrm{CaO}$, with the main difference being that the external scale was made of mixed $\mathrm{Ca}-\mathrm{Cr}$ silicates; it contained $\mathrm{Cr}_{2} \mathrm{O}_{3}$ too, but not as a continuous layer. Furthermore, no $\mathrm{Al}_{2} \mathrm{O}_{3}$ layer formed at the internal oxidation front.

The $\mathrm{SiO}_{2}-\mathrm{Na}_{2} \mathrm{SO}_{4}$ deposit produced a molten silicate, which again dissolved large amounts of $\mathrm{Al}_{2} \mathrm{O}_{3}$. A thick $\mathrm{Cr}_{2} \mathrm{O}_{3}$ layer was present above most of the internal $\mathrm{Al}_{2} \mathrm{O}_{3}$ (left panel of Fig. 10d), but in some locations there appeared to be no external scale, and instead $\mathrm{Cr}_{2} \mathrm{O}_{3}$ was found dispersed in the silicate (right panel of Fig. 10d). An external $\mathrm{Al}_{2} \mathrm{O}_{3}$ scale was present locally.

With the $\mathrm{SiO}_{2}-\mathrm{CaO}-\mathrm{Na}_{2} \mathrm{SO}_{4}$ mixture, a relatively thick scale formed, which contained various phases such as $\mathrm{Ca}-\mathrm{Cr}$ silicate, $\mathrm{C}_{x} \mathrm{~A}_{y}, \mathrm{Ca}-\mathrm{Cr}$ sulfo-aluminate, $\mathrm{Cr}_{2} \mathrm{O}_{3}$ or $\mathrm{CoCr}_{2} \mathrm{O}_{4}$. Underneath, internal oxidation was relatively shallow and locally an external $\mathrm{Al}_{2} \mathrm{O}_{3}$ layer was present (Fig. 10e).

Finally, exposure to $\mathrm{SiO}_{2}-\mathrm{Al}_{2} \mathrm{O}_{3}-\mathrm{CaO}-\mathrm{Na}_{2} \mathrm{SO}_{4}$ resulted in both regions of external $\mathrm{Al}_{2} \mathrm{O}_{3}$ scaling and regions of internal oxidation (Fig. 10f). In the latter case, the affected depth was variable, as was the morphology of the reaction front, which locally featured a continuous $\mathrm{Al}_{2} \mathrm{O}_{3}$ layer. The corrosion product also contained an external, more or less continuous scale of mixed alumino-silicate, Cr-rich silicate and $\mathrm{Cr}_{2} \mathrm{O}_{3}$. 

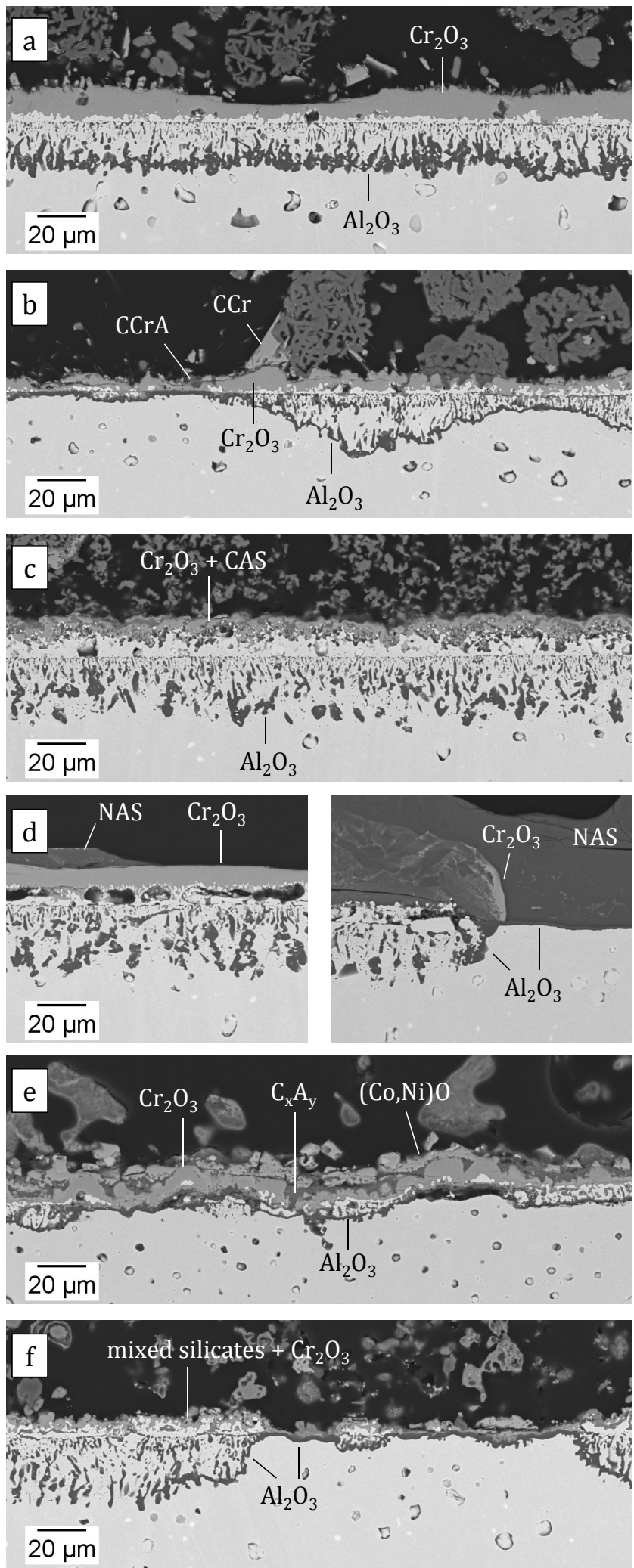

Figure 10: Corrosion products observed on alloy $0 \beta-35 \mathrm{Cr}$ after $50 \mathrm{~h}$ reaction in $\mathrm{CO}_{2}-20 \mathrm{H}_{2} \mathrm{O}-1.6 \mathrm{O}_{2}$ at $1100{ }^{\circ} \mathrm{C}$ with (a) $\mathrm{Al}_{2} \mathrm{O}_{3}-40 \mathrm{CaO}$; (b) $\mathrm{Al}_{2} \mathrm{O}_{3}-40 \mathrm{CaO}-10 \mathrm{Na}_{2} \mathrm{SO}_{4}$; (c) $\mathrm{SiO}_{2}-40 \mathrm{CaO}$; (d) $\mathrm{SiO}_{2}-10 \mathrm{Na}_{2} \mathrm{SO}_{4}$; (e) $\mathrm{SiO}_{2}-40 \mathrm{CaO}-10 \mathrm{Na}_{2} \mathrm{SO}_{4}$; (f) $\mathrm{SiO}_{2}-25 \mathrm{Al}_{2} \mathrm{O}_{3}-40 \mathrm{CaO}$ $10 \mathrm{Na}_{2} \mathrm{SO}_{4}$. Mixed compound notation: C: $\mathrm{CaO} ; \mathrm{A}: \mathrm{Al}_{2} \mathrm{O}_{3} ; \mathrm{Cr}: \mathrm{Cr}_{2} \mathrm{O}_{3} ; \mathrm{N}: \mathrm{Na}_{2} \mathrm{O} ; \mathrm{S}: \mathrm{SiO}_{2}$. 

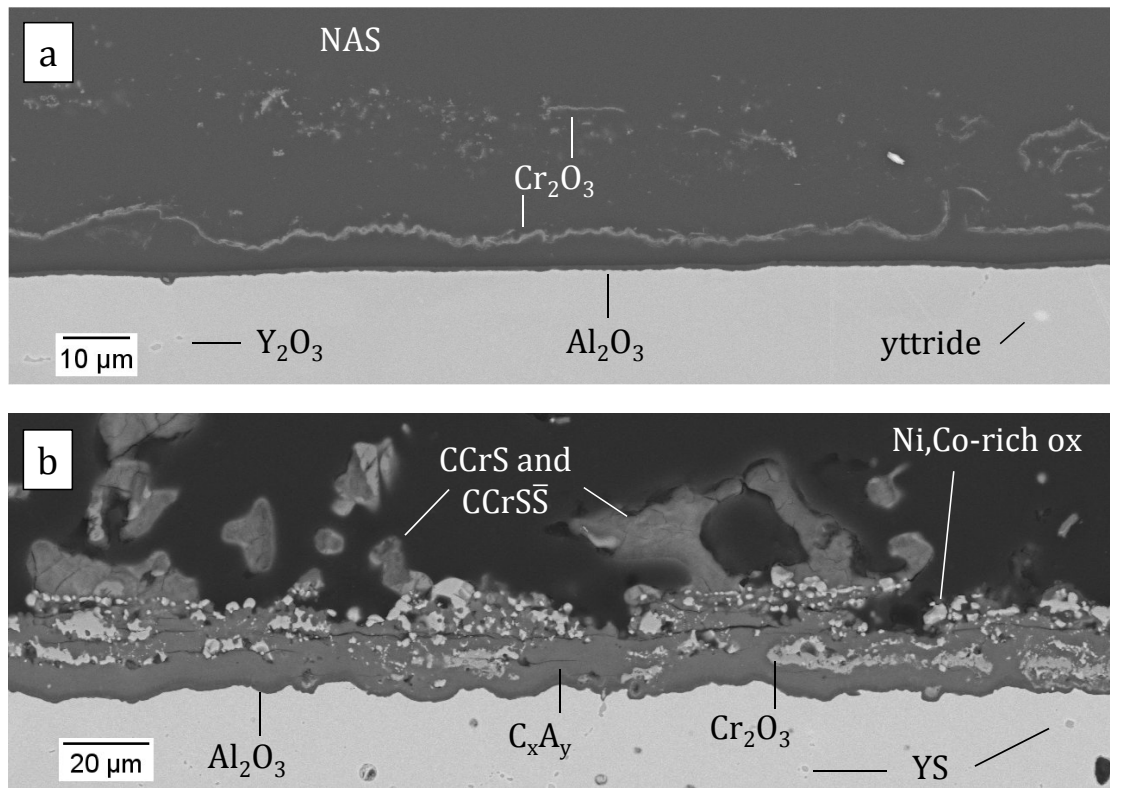

Figure 11: Corrosion products observed on alloy $0 \beta-19 \mathrm{Cr}$ after $50 \mathrm{~h}$ reaction in $\mathrm{CO}_{2}-$ $20 \mathrm{H}_{2} \mathrm{O}-1.6 \mathrm{O}_{2}$ at $1100{ }^{\circ} \mathrm{C}$ with (a) $\mathrm{SiO}_{2}-10 \mathrm{Na}_{2} \mathrm{SO}_{4}$; (b) $\mathrm{SiO}_{2}-40 \mathrm{CaO}-10 \mathrm{Na}_{2} \mathrm{SO}_{4}$. Mixed compound notation: C: $\mathrm{CaO} ; \mathrm{A}: \mathrm{Al}_{2} \mathrm{O}_{3} ; \mathrm{Cr}: \mathrm{Cr}_{2} \mathrm{O}_{3} ; \mathrm{N}: \mathrm{Na}_{2} \mathrm{O} ; \mathrm{S}: \mathrm{SiO}_{2} ; \overline{\mathrm{S}}: \mathrm{SO}_{3}$.

\subsection{Additional exposures to model deposits}

In order to better understand the effects of alloy phase fraction and phase composition on deposit-induced corrosion, alloys $0 \beta-19 \mathrm{Cr}, 0 \beta-35 \mathrm{Cr}, 17 \beta-16 \mathrm{Cr}, 16 \beta-30 \mathrm{Cr}$, $63 \beta-10 \mathrm{Cr}, 63 \beta-18 \mathrm{Cr}, 100 \beta-5 \mathrm{Cr}$ and $100 \beta-8 \mathrm{Cr}$ were exposed to the $\mathrm{SiO}_{2}-\mathrm{Al}_{2} \mathrm{O}_{3}$ $\mathrm{CaO}-\mathrm{Na}_{2} \mathrm{SO}_{4}$ mixture and to the fly-ash (Table 2). With both deposits, only the alloys $16 \beta-30 \mathrm{Cr}$ (similar to $13 \beta-27 \mathrm{Cr}$ studied above) and $0 \beta-35 \mathrm{Cr}$ (see above) alloys experienced internal oxidation, while all others formed external $\mathrm{Al}_{2} \mathrm{O}_{3}$. Thus the $\beta$-rich compositions were immune, and in the $\gamma$-rich region, only alloys with high $\mathrm{Cr}$ levels were susceptible to degradation.

The same eight alloys were exposed to pure $\mathrm{CaO}$. The $\beta$-rich alloys ( $63 \beta$ and $100 \beta$ ) only formed $\mathrm{C}_{x} \mathrm{~A}_{y}-\mathrm{Al}_{2} \mathrm{O}_{3}$ scales, while the $\gamma$-rich alloys $(0 \beta$ and $16 \beta)$ also produced molten $\mathrm{CCr}$. As could be expected, the quantity of $\mathrm{CCr}$ increased with increasing $\mathrm{Cr}$ and decreasing $\mathrm{Al}$ concentration in the alloy.

The alloy sensitivity to molten NS was studied using alloy $0 \beta-19$ Cr. Exposure to $\mathrm{SiO}_{2}-\mathrm{Na}_{2} \mathrm{SO}_{4}$ resulted in external $\mathrm{Al}_{2} \mathrm{O}_{3}$ formation (Fig. 11a). As observed for alloys $13 \beta-27 \mathrm{Cr}$ and $0 \beta-35 \mathrm{Cr}$, large amounts of $\mathrm{Al}$ were dissolved in the silicate; yet this did not lead to $\mathrm{Al}_{2} \mathrm{O}_{3}$ breakdown, despite the alloy having a lower $\mathrm{Al}$ concentration than $13 \beta-27 \mathrm{Cr}$. Alloy $0 \beta-19 \mathrm{Cr}$ was also exposed to $\mathrm{SiO}_{2}-\mathrm{CaO}-\mathrm{Na}_{2} \mathrm{SO}_{4}$, which involved reaction with both $\mathrm{CaO}$ and $\mathrm{NS}$. The alloy produced a thick $\mathrm{C}_{x} \mathrm{~A}_{y}$ scale with $\mathrm{Cr}_{2} \mathrm{O}_{3}$ and $(\mathrm{Co}, \mathrm{Ni}) \mathrm{O}$ embedded, and a continuous $\mathrm{Al}_{2} \mathrm{O}_{3}$ layer at the base (Fig. 11b). Internal oxidation of $\mathrm{Al}$ occurred in a few isolated cases, but mostly the alloy passivated.

The deposits used so far had relatively large concentrations of $\mathrm{CaO}$ (40 wt. \%) or $\mathrm{Na}_{2} \mathrm{SO}_{4}$ (10 wt. \%). While these levels are relevant to some industrial deposits, e.g., class $\mathrm{C}$ fly-ash, they are large relative to other applications such as 
aero engines, where the CMAS tend to be much richer in $\mathrm{SiO}_{2}$. An additional series of experiments was conducted using alloy $13 \beta-27 \mathrm{Cr}$ and deposits covering a broader range of compositions. Briefly, these included mixtures based on $\mathrm{SiO}_{2}-$ $25 \mathrm{Al}_{2} \mathrm{O}_{3}-10 \mathrm{CaO}-10 \mathrm{Fe}_{2} \mathrm{O}_{3}-5 \mathrm{MgO}$, with or without 5 wt. $\% \mathrm{~K}_{2} \mathrm{SO}_{4}$, or with $\mathrm{CaO}$ concentrations varying up to $46 \mathrm{wt}$. $\%$, the other constituents being kept in constant proportions. Also tested was a mixture with the same composition as the fly-ash used previously, but with no sulfate. None of these deposits led to significant degradation of the alloy: variable amounts of Cr-rich oxide formed, but always above an external $\mathrm{Al}_{2} \mathrm{O}_{3}$ scale, no internal oxidation occurred.

\section{Discussion}

The present results show that NiCoCrAlY alloys that are intrinsically $\mathrm{Al}_{2} \mathrm{O}_{3}$-formers (i.e., when free of a deposit) are at risk of switching to internal $\mathrm{Al}_{2} \mathrm{O}_{3}$ and external $\mathrm{Cr}_{2} \mathrm{O}_{3}$ formation when exposed to certain types of oxide-sulfate deposits at $1100{ }^{\circ} \mathrm{C}$. The attack is localized, and its severity depends on both deposit and alloy composition.

The processes underlying this deposit-induced attack can ultimately be understood in terms of primary reaction modes involving $\mathrm{CaO}, \mathrm{SiO}_{2}$ and $\mathrm{Na}_{2} \mathrm{SO}_{4}$. The reaction of $\mathrm{CaO}$ with $\mathrm{Cr}$ to form a liquid chromate rapidly consumes the Cr-rich $\gamma$ phase, while its reaction with $\mathrm{Al}_{2} \mathrm{O}_{3}$ to form $\mathrm{Ca}$ aluminates results in enhanced $\mathrm{Al}$ depletion [25]. On the other hand, $\mathrm{SiO}_{2}$ and $\mathrm{Na}_{2} \mathrm{SO}_{4}$ form a molten silicate with high $\mathrm{Al}$ solubility. The dissolution of thermally grown $\mathrm{Al}_{2} \mathrm{O}_{3}$ in this phase has the same effect as $\mathrm{C}_{x} \mathrm{~A}_{y}$ formation: reducing the $\mathrm{Al}_{2} \mathrm{O}_{3}$ thickness causes an increased oxidation rate, and a greater $\mathrm{Al}$ flux is required to sustain external scaling, which the alloy may fail to accommodate. Variations of these primary modes are observed in multi-component deposits due to interactions between constituents. In particular, $\mathrm{SiO}_{2}$ and $\mathrm{Na}_{2} \mathrm{SO}_{4}$ affect $\mathrm{CCr}$ and $\mathrm{C}_{x} \mathrm{~A}_{y}$ formation, in different ways. These interactions are schematically summarized in Fig. 12, which maps the nature and potential severity of $\gamma$-rich alloy degradation as a function of deposit composition. The influence of each constituent will be discussed in subsequent sections.

Regarding the metal system, alloys with both high $\mathrm{Cr}$ and high $\gamma$ fractions were most affected by the deposits. This is related to the nature of the processes identified above: the reaction of thermally grown $\mathrm{Al}_{2} \mathrm{O}_{3}$ with either $\mathrm{CaO}$ or NS affects the $\mathrm{Al}$ mass balance, and is therefore most detrimental to $\gamma$-rich alloys, which have a smaller Al reservoir. Similarly, CCr formation is a concern for these alloys both because it preferentially consumes the Cr-rich $\gamma$-phase, and because it does so as long as no continuous $\mathrm{Al}_{2} \mathrm{O}_{3}$ layer is established, which again depends on the $\mathrm{Al}$ content. The importance of the attack can be conveniently described in terms of a shift in the minimum $\mathrm{Al}$ concentration required to form an external $\mathrm{Al}_{2} \mathrm{O}_{3}$ scale. This is done in Fig. 13, which was inspired by the oxide map developed by Giggins and Pettit for the oxidation of $\mathrm{NiCrAl}$ alloys [36]. As indicated in this figure, an expanded internal/external $\mathrm{Al}_{2} \mathrm{O}_{3}$ transition region exists in the presence of the oxide-sulfate deposit. In addition, a slight increase in the $\mathrm{Y}$ concentration, from 0.1 to 0.3 at. $\%$, triggered localized attack of the $57 \beta-15 \mathrm{Cr}$ alloy exposed to the fly-ash. This was due to the increased number and size of $\mathrm{Y}-\mathrm{Al}-\mathrm{O}$ precipitates, which served as initiation sites for accelerated reaction (Fig. 4). Local $\mathrm{Al}_{2} \mathrm{O}_{3}$ scale disruption due 


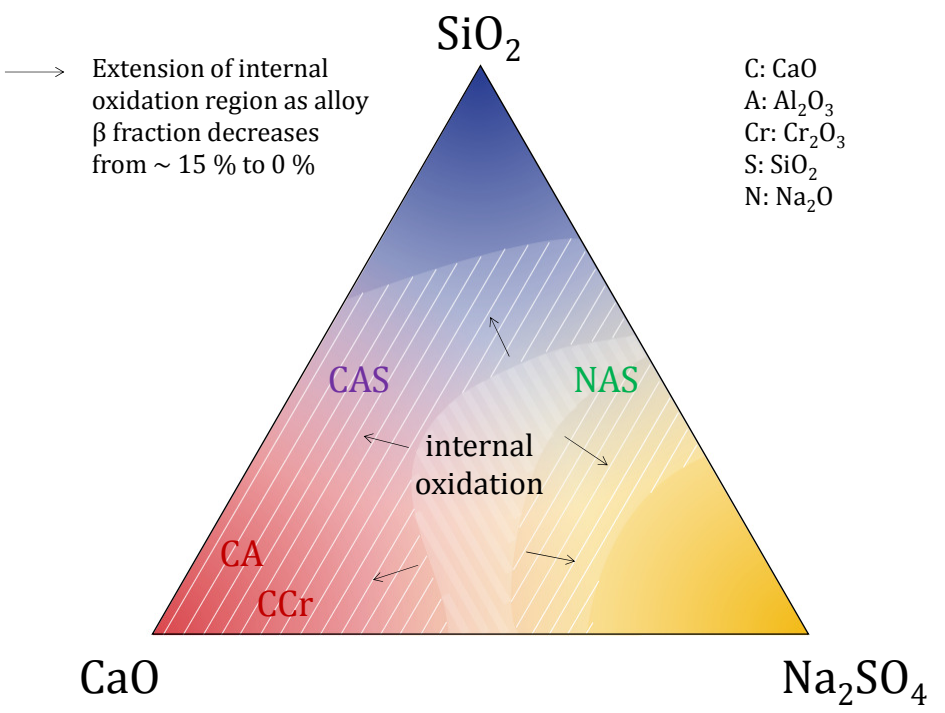

Figure 12: Schematic map of primary reaction modes involved in the deposit-induced attack of $\mathrm{Cr}$-rich, $\gamma$-rich NiCoCrAlY alloys at $1100{ }^{\circ} \mathrm{C}$. The map represents the alloy-deposit reaction products (aluminates, aluminosilicates, and chromates) in a composition space defined by three deposit constituents: $\mathrm{SiO}_{2}, \mathrm{CaO}$, and $\mathrm{Na}_{2} \mathrm{SO}_{4}$. Deposit compositions causing internal oxidation are represented by hatching.

to highly reactive Y-rich oxide particles was previously reported for MCrAlY alloys exposed to $\mathrm{Na}_{2} \mathrm{SO}_{4}$ in type II hot corrosion conditions [37].

The reaction mechanism associated with multi-component deposits is best described from the morphologies developed after varying durations. This is discussed in detail in Ref. [26], in which results obtained for exposure times ranging from 20 min to $250 \mathrm{~h}$ are reported. As an example, Fig. 14 shows alloy $13 \beta-27 \mathrm{Cr}$ after $1 \mathrm{~h}$ exposure to the model deposit with the same composition as the fly-ash (Table 2). An external $\mathrm{Al}_{2} \mathrm{O}_{3}$ scale is seen to have formed initially, and failed locally. The scale is still present but lost its protective character, as oxides of $\mathrm{Cr}, \mathrm{Ni}$ and $\mathrm{Co}$ are found above it in quantities larger than had formed initially. Alumina intrusions are seen to grow from the scale into the alloy. Due to the localized nature of the attack, several evolutionary stages are visible on the same micrograph: the intrusions develop into the internal oxidation morphology typical of longer exposures, with $\mathrm{Cr}_{2} \mathrm{O}_{3}$ growing as an external layer and the internal oxide particles coalescing into a continuous $\mathrm{Al}_{2} \mathrm{O}_{3}$ layer at the reaction front. This morphology reflects a steady-state and was not seen to evolve further, at least up to $250 \mathrm{~h}$ in isothermal conditions, although in some cases the Al-free metal between the internal $\mathrm{Al}_{2} \mathrm{O}_{3}$ also oxidized (Fig. 5). Excepting the latter aspect, the morphology is quite similar to that developed by certain wrought austenitic Ni-base alloys classified as "marginal $\mathrm{Al}_{2} \mathrm{O}_{3}$-formers". In general, these alloys grow external $\mathrm{Al}_{2} \mathrm{O}_{3}$ at low temperatures and internal $\mathrm{Al}_{2} \mathrm{O}_{3}$ plus external $\mathrm{Cr}_{2} \mathrm{O}_{3}$ at higher temperatures. Recently published studies of alloy 602 CA $[39,40]$, for example, illustrate these similarities. Although the present NiCoCrAlY alloys had higher $\mathrm{Al}$ and $\mathrm{Cr}$ concentrations, the resemblance with $602 \mathrm{CA}$ reflects the effect of the deposits on the oxide map (Fig. 13).

The link between primary reaction modes identified using unary or binary de- 


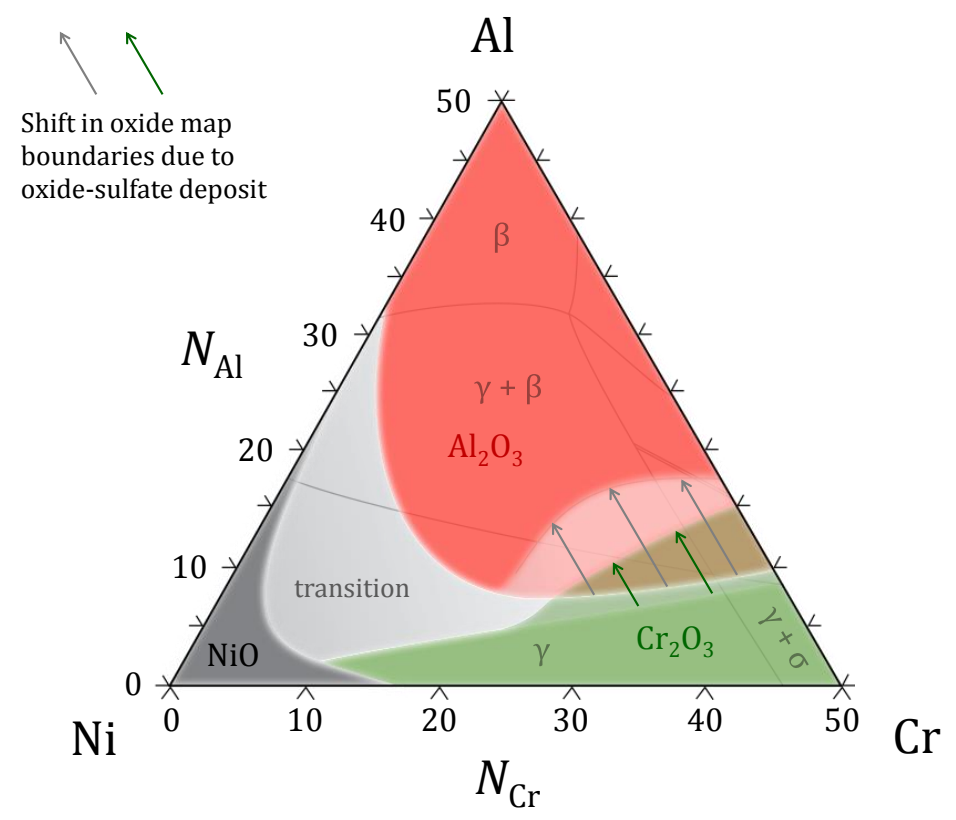

Figure 13: Map showing the effect of sulfate-oxide deposits on the oxidation of NiCoCrAlY alloys at $1100{ }^{\circ} \mathrm{C}$. The boundaries were determined from work by Giggins and Pettit [36] and our work [38] on $\mathrm{NiCrAl}$ alloys. "NiO" denotes alloy compositions which form external $\mathrm{NiO}$ and internal $\mathrm{Al}_{2} \mathrm{O}_{3}$ and $\mathrm{Cr}_{2} \mathrm{O}_{3}$; " $\mathrm{Cr}_{2} \mathrm{O}_{3}$ " denotes compositions which form external $\mathrm{Cr}_{2} \mathrm{O}_{3}$ and internal $\mathrm{Al}_{2} \mathrm{O}_{3}$; " $\mathrm{Al}_{2} \mathrm{O}_{3}$ " denotes compositions which form external $\mathrm{Al}_{2} \mathrm{O}_{3}$ exclusively; "transition" denotes compositions subject to localized internal oxidation of Al. The alloy map is superimposed on an isothermal section of the NiCoCrAl system with a constant 30 at. \% Co, generated with the CRALDAD database [30].

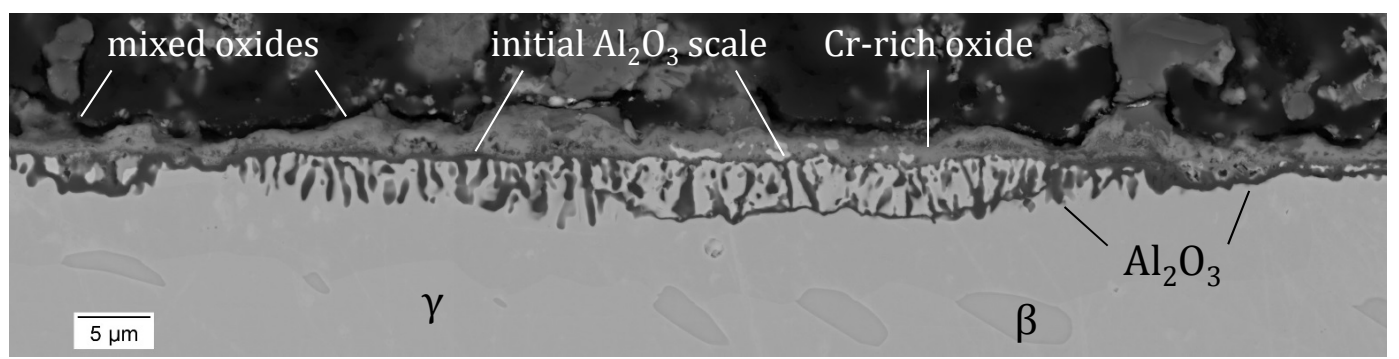

Figure 14: Corrosion product formed on alloy $13 \beta-27 \mathrm{Cr}$ exposed $1 \mathrm{~h}$ to a model deposit with the same composition as the fly-ash (Table 2) in $\mathrm{CO}_{2}-20 \mathrm{H}_{2} \mathrm{O}$ at $1100{ }^{\circ} \mathrm{C}$. 
posits and the corrosion process associated with higher-order deposits is deduced from the composition of the latter. Specifically, in the case of the $13 \beta-27 \mathrm{Cr}$ alloy: (i) the lowest order mixture causing internal oxidation was the ternary $\mathrm{SiO}_{2}-\mathrm{CaO}$ $\mathrm{Na}_{2} \mathrm{SO}_{4}$; (ii) in higher order deposits, only those with both a high $\mathrm{CaO}$ concentration and some $\mathrm{Na}_{2} \mathrm{SO}_{4}$ caused internal oxidation; (iii) in those cases, the corrosion products were similar in nature and morphology to those observed with $\mathrm{SiO}_{2}-\mathrm{CaO}$ $\mathrm{Na}_{2} \mathrm{SO}_{4}$. It follows that for this particular alloy composition, the co-occurrence of reaction modes involving $\mathrm{CaO}$ and $\mathrm{NS}$ was necessary to induce $\mathrm{Al}_{2} \mathrm{O}_{3}$ failure. This was not the case for alloy $0 \beta-35 \mathrm{Cr}$, which is closer to the threshold for external $\mathrm{Al}_{2} \mathrm{O}_{3}$ formation and where each reaction mode separately caused internal oxidation. Another consequence is that corrosion by multi-component deposits can be analyzed in terms of the interactions between thermally grown $\mathrm{Al}_{2} \mathrm{O}_{3}$ and deposit constituents, and the consequences thereof on the $\mathrm{Al}$ mass balance and $\mathrm{Al}_{2} \mathrm{O}_{3}$ stability.

\subsection{Thermodynamic considerations}

At $1100{ }^{\circ} \mathrm{C}$, the $p_{\mathrm{SO}_{3}}$ corresponding to $\mathrm{CaO} / \mathrm{CaSO}_{4}$ equilibrium is calculated using data compiled by Barin [41] to be $9 \times 10^{-7}$ atm, so that $\mathrm{CaO}$ should be stable under the current testing conditions. Analysis by XRD of powders reacted in $\mathrm{CO}_{2}-\mathrm{H}_{2} \mathrm{O}-$ $\mathrm{O}_{2}$ confirmed that $\mathrm{CaO}$ was indeed the predominant species. Sodium sulfate, in comparison, is much more stable relative to $\mathrm{Na}_{2} \mathrm{O}$, as the $p_{\mathrm{SO}_{3}}$ for $\mathrm{Na}_{2} \mathrm{O} / \mathrm{Na}_{2} \mathrm{SO}_{4}$ equilibrium is $2 \times 10^{-14} \mathrm{~atm}$, a figure smaller than the impurity level in the reaction gas - no $\mathrm{Na}_{2} \mathrm{O}$ was detected in the reacted samples. However, in the presence of oxides such as $\mathrm{SiO}_{2}$, the relative stability of $\mathrm{Na}_{2} \mathrm{SO}_{4}$ is reduced: for example, the $p_{\mathrm{SO}_{3}}$ associated with the equilibrium

$$
\mathrm{Na}_{2} \mathrm{SO}_{4}+\mathrm{SiO}_{2}=\mathrm{Na}_{2} \mathrm{SiO}_{3}+\mathrm{SO}_{3}
$$

is $5 \times 10^{-6}$ atm, which is significant, and indeed $\mathrm{Na}_{2} \mathrm{SO}_{4}$ reacted to form $\mathrm{Na}_{2} \mathrm{SiO}_{3}$. Incomplete thermodynamic data do not allow accurate calculation at $1100{ }^{\circ} \mathrm{C}$, but extrapolation from lower temperatures yields an even higher $p_{\mathrm{SO}_{3}}$ value if $\mathrm{Na}_{2} \mathrm{Si}_{3} \mathrm{O}_{7}$, which is closer to measured silicate compositions, is considered instead of $\mathrm{Na}_{2} \mathrm{SiO}_{3}$. Thus, either a significant $p_{\mathrm{SO}_{3}}$ or a very low $\mathrm{SiO}_{2}$ activity would be needed to prevent the formation of the liquid silicate.

In conditions where $\mathrm{Na}$ is present as a sulfate, the question of its interaction with the other deposit constituents is of interest. With $\mathrm{CaO}$ being a very basic oxide, its reaction with $\mathrm{Na}_{2} \mathrm{SO}_{4}$ involves $\mathrm{CaSO}_{4}$. As noted above, the latter is not stable at unit activity in a low $p_{\mathrm{SO}_{3}}$ gas. However, $\mathrm{CaO}$ may dissolve in liquid $\mathrm{Na}_{2} \mathrm{SO}_{4}$ : the equilibrium $\mathrm{CaSO}_{4}$ fraction in the $\mathrm{Na}_{2} \mathrm{SO}_{4}-\mathrm{CaSO}_{4}$ solution, which is wide at $1100{ }^{\circ} \mathrm{C}$ [42], depends on the environmental $\mathrm{SO}_{3}$ level. Alumina is amphoteric, and is expected to form $\mathrm{NaAlO}_{2}$ in a basic environment [43]. The $p_{\mathrm{SO}_{3}}$ associated with the equilibrium

$$
\mathrm{Na}_{2} \mathrm{SO}_{4}+\mathrm{Al}_{2} \mathrm{O}_{3}=2 \mathrm{NaAlO}_{2}+\mathrm{SO}_{3}
$$

is $8 \times 10^{-9}$ atm, which is small and suggests that $\mathrm{NaAlO}_{2}$ would not exist at unit activity in the present conditions. The $\mathrm{Na}_{2} \mathrm{O}-\mathrm{NaAlO}_{2}$ system contains a liquid aluminate, but the eutectic temperature $\left(1132{ }^{\circ} \mathrm{C}\right.$ at 5 mol. $\% \mathrm{Al}_{2} \mathrm{O}_{3}$ [35]) is slightly higher than the present reaction temperature. Results on hot corrosion of $\mathrm{Al}_{2} \mathrm{O}_{3}$ at $1000{ }^{\circ} \mathrm{C}[44]$ also indicate that the aluminate solubility in molten $\mathrm{Na}_{2} \mathrm{SO}_{4}$ is low, 

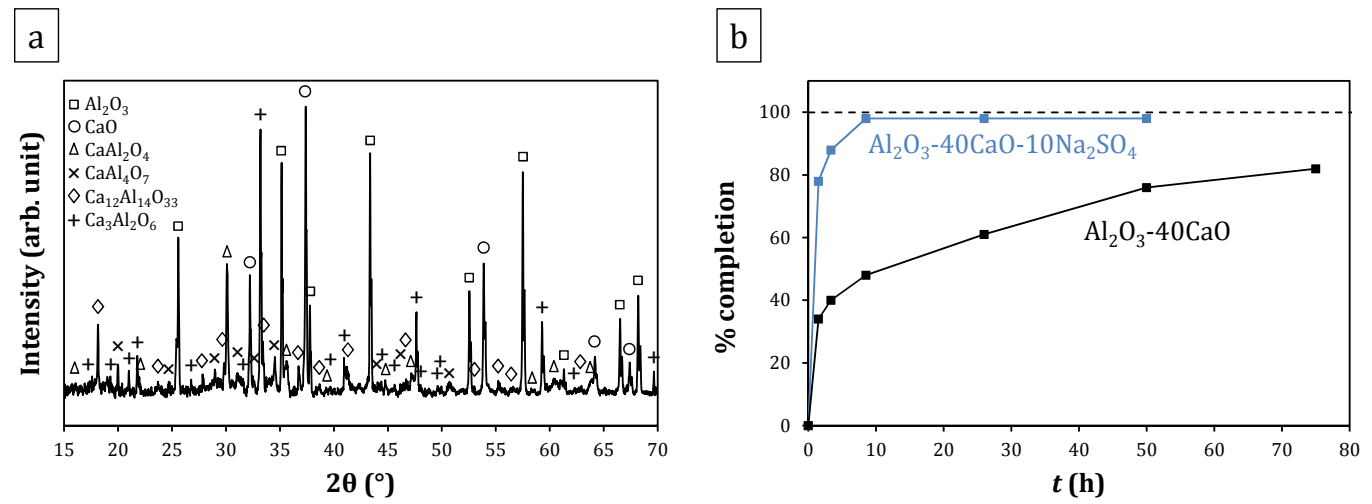

Figure 15: Analysis of $x \mathrm{CaO}+y \mathrm{Al}_{2} \mathrm{O}_{3}=\mathrm{C}_{x} \mathrm{~A}_{y}$ reaction kinetics during annealing of $\mathrm{Al}_{2} \mathrm{O}_{3}-40 \mathrm{CaO}$ and $\mathrm{Al}_{2} \mathrm{O}_{3}-40 \mathrm{CaO}-10 \mathrm{Na}_{2} \mathrm{SO}_{4}$ powder mixtures in air at $1100{ }^{\circ} \mathrm{C}$. (a) Example of XRD pattern $\left(\mathrm{Al}_{2} \mathrm{O}_{3}-40 \mathrm{CaO}, 8.5 \mathrm{~h}\right.$ ); (b) extent of completion calculated by adding the mole fractions of all $\mathrm{C}_{x} \mathrm{~A}_{y}$ compounds, determined from XRD patterns.

although it can be increased by the simultaneous dissolution of $\mathrm{SiO}_{2}$. Indeed, alloy $13 \beta-27 \mathrm{Cr}$ was exposed to pure $\mathrm{Na}_{2} \mathrm{SO}_{4}$ in dry air, and formed a stable $\mathrm{Al}_{2} \mathrm{O}_{3}$ scale - no hot corrosion was observed.

\subsection{Role of $\mathrm{Na}_{2} \mathrm{SO}_{4}$ in the reaction process}

Despite the absence of an $\mathrm{Na}_{2} \mathrm{SO}_{4}$-induced hot-corrosion process, the addition of $\mathrm{Na}_{2} \mathrm{SO}_{4}$ to $\mathrm{Al}_{2} \mathrm{O}_{3}-\mathrm{CaO}$ did increase the reactivity of $\mathrm{CaO}$, in that it resulted in a thicker $\mathrm{C}_{x} \mathrm{~A}_{y}$ scale on alloy $13 \beta-27 \mathrm{Cr}$ (Fig. 6). In order to examine the role of $\mathrm{Na}_{2} \mathrm{SO}_{4}, \mathrm{Al}_{2} \mathrm{O}_{3}-\mathrm{CaO}$ and $\mathrm{Al}_{2} \mathrm{O}_{3}-\mathrm{CaO}-\mathrm{Na}_{2} \mathrm{SO}_{4}$ powder mixtures were annealed at $1100{ }^{\circ} \mathrm{C}$ in $\mathrm{Al}_{2} \mathrm{O}_{3}$ crucibles, with no metal specimen, and the evolution of phase constitution was studied by XRD. Fig. 15a shows a typical diffraction pattern, where reactants $\left(\mathrm{CaO}, \mathrm{Al}_{2} \mathrm{O}_{3}\right)$ and products $\left(\mathrm{C}_{x} \mathrm{~A}_{y}\right)$ are identified. Semi-quantitative analysis of patterns recorded after several reaction times using a built-in tool in the XRD processing software provided an estimation of the powder compositions. The mole fractions of all $\mathrm{C}_{x} \mathrm{~A}_{y}$ compounds were added to determine an accumulated extent of completion for the $x \mathrm{CaO}+y \mathrm{Al}_{2} \mathrm{O}_{3}=\mathrm{C}_{x} \mathrm{~A}_{y}$ reactions. This extent is also defined as $1-x_{\mathrm{Al}_{2} \mathrm{O}_{3}}-x_{\mathrm{CaO}}-x_{\mathrm{Na}_{2} \mathrm{SO}_{4}}$, where $x_{i}$ is the mole fraction of phase $i$. Extents of completion are plotted as a function of reaction time for both powder mixtures in Fig. 15b. The plots indicate that adding $\mathrm{Na}_{2} \mathrm{SO}_{4}$ significantly accelerated the reaction of $\mathrm{CaO}$ with $\mathrm{Al}_{2} \mathrm{O}_{3}$ to form $\mathrm{C}_{x} \mathrm{~A}_{y}$ phases. As a further study, $\mathrm{Al}_{2} \mathrm{O}_{3}$ and $\mathrm{CaO}$ powders were mixed in a large excess of $\mathrm{Na}_{2} \mathrm{SO}_{4}$ and annealed $20 \mathrm{~h}$ at $1100{ }^{\circ} \mathrm{C}$. The molten sulfate was found by SEM-EDS to contain no measurable Al but on average 1 at. \% Ca, i.e., about 8 mol. \% $\mathrm{CaSO}_{4}$ in $\mathrm{Na}_{2} \mathrm{SO}_{4}$. Based on this observation, it is concluded that the molten sulfate mediated the conversion of $\mathrm{CaO}$ and $\mathrm{Al}_{2} \mathrm{O}_{3}$ to $\mathrm{C}_{x} \mathrm{~A}_{y}$ by facilitating $\mathrm{Ca}$ transport. This occurs even though pure $\mathrm{CaSO}_{4}$ is not stable relative to $\mathrm{CaO}$; rather, $\mathrm{CaSO}_{4}$ exists at activity less than one as a solute in $\mathrm{Na}_{2} \mathrm{SO}_{4}$.

Exposure of alloy $13 \beta-27 \mathrm{Cr}$ to $\mathrm{CaO}-\mathrm{Na}_{2} \mathrm{SO}_{4}$ locally led to internal oxidation (Fig. 7), which was not observed with $\mathrm{CaO}$ alone. Exactly how $\mathrm{Na}_{2} \mathrm{SO}_{4}$ triggered internal oxidation is not clear at this stage, since the activity of pure $\mathrm{CaO}$ cannot be 
increased, but this result further exemplifies the detrimental effect molten $\mathrm{Na}_{2} \mathrm{SO}_{4}$ can have on $\mathrm{CaO}$-induced attack. Remarkably, in the case of alloy $0 \beta-35 \mathrm{Cr}$, while exposure to $\mathrm{Al}_{2} \mathrm{O}_{3}-\mathrm{CaO}$ or $\mathrm{SiO}_{2}-\mathrm{CaO}$ led to uniform internal oxidation, the addition of $\mathrm{Na}_{2} \mathrm{SO}_{4}$ to either deposit tended to reduce the internal oxidation depth, to the point where $\mathrm{Al}_{2} \mathrm{O}_{3}$ was locally present as an external scale (compare Figs. 10a-b, and Figs. 10c-e). How $\mathrm{Na}_{2} \mathrm{SO}_{4}$ favored passivation in this case requires further study.

The presence of $\mathrm{Na}_{2} \mathrm{SO}_{4}$ also led to the establishment of a locally elevated $\mathrm{S}$ activity at the metal surface, as shown by the occasional presence of internal Y sulfides (for example in Fig. 11b). This had important implications in the early-stage reaction, which are presented in a companion publication [26]. In the presence of an excess of $\mathrm{SiO}_{2}, \mathrm{Na}_{2} \mathrm{SO}_{4}$ effects can only be short-lived, since $\mathrm{Na}_{2} \mathrm{SO}_{4}$ is eventually consumed to form $\mathrm{Na}$ silicate. With $\mathrm{SiO}_{2}$-free deposits, however, $\mathrm{Na}_{2} \mathrm{SO}_{4}$ additions lead to enhanced $\mathrm{Al}_{2} \mathrm{O}_{3}$ spallation (Figs. 6 and 7 ) due to the presence of sulfur, which is known to reduce scale adherence [45-47].

\subsection{Effects of $\mathrm{Al}_{2} \mathrm{O}_{3}$ and $\mathrm{SiO}_{2}$}

The addition of $\mathrm{Al}_{2} \mathrm{O}_{3}$ or $\mathrm{SiO}_{2}$ to $\mathrm{CaO}$ reduced the quantity of $\mathrm{CCr}$ formed on alloy $13 \beta-27 \mathrm{Cr}$ prior to the establishment of external $\mathrm{C}_{x} \mathrm{~A}_{y}-\mathrm{Al}_{2} \mathrm{O}_{3}$. This mitigating effect was greater yet in the case of alloy $0 \beta-35 \mathrm{Cr}$, as $\mathrm{CCr}$ consumed over $150 \mu \mathrm{m}$ of metal during reaction with $\mathrm{CaO}$ [25], but was not observed here with $\mathrm{Al}_{2} \mathrm{O}_{3}-\mathrm{CaO}$ or $\mathrm{SiO}_{2}-\mathrm{CaO}$. This can be associated with a reduced reactivity of $\mathrm{CaO}$ toward the alloy, due to the formation of Ca aluminate or silicate in the deposit.

However, $\mathrm{Al}_{2} \mathrm{O}_{3}$ and $\mathrm{SiO}_{2}$ do not have equivalent effects. For instance, on alloy $0 \beta-35 \mathrm{Cr}$ exposed to $\mathrm{Al}_{2} \mathrm{O}_{3}-\mathrm{CaO}$, an external $\mathrm{Cr}_{2} \mathrm{O}_{3}$ layer was formed above the internal oxidation zone, and the alloy eventually repassivated (Fig. 10a). With $\mathrm{SiO}_{2}-\mathrm{CaO}$, both $\mathrm{Cr}_{2} \mathrm{O}_{3}$ and $\mathrm{Ca}-\mathrm{Cr}$ silicates formed, but not as a continuous layer (Fig. 10c). In this case the alloy did not repassivate, and internal oxidation penetrated deeper. It is concluded that, when present as a continuous layer, $\mathrm{Cr}_{2} \mathrm{O}_{3}$ lowered the $p_{\mathrm{O}_{2}}$ at the metal surface, which resulted in a reduced inward $\mathrm{O}$ flux, and favored the establishment of a new $\mathrm{Al}_{2} \mathrm{O}_{3}$ layer, as opposed to continued internal oxidation. In the presence of $\mathrm{SiO}_{2}$, the formation of a $\mathrm{Ca}-\mathrm{Cr}$ silicate, likely uvarovite $\mathrm{Ca}_{3} \mathrm{Cr}_{2} \mathrm{Si}_{3} \mathrm{O}_{12}$ [48], prevented the establishment of a continuous $\mathrm{Cr}_{2} \mathrm{O}_{3}$ layer, and therefore repassivation. A pseudo-ternary compound exists in the $\mathrm{CaO}$ $\mathrm{Al}_{2} \mathrm{O}_{3}-\mathrm{Cr}_{2} \mathrm{O}_{3}$ system (chromate aluminate sodalite $\mathrm{Ca}_{8}\left[\mathrm{Al}_{12} \mathrm{O}_{24}\right]\left(\mathrm{CrO}_{4}\right)_{2}[49,50]$, but was not observed to form here.

\section{Conclusions}

Applying sulfate-oxide deposits to $\mathrm{Al}_{2} \mathrm{O}_{3}$-forming NiCoCrAlY alloys led to enhanced degradation due to the presence of $\mathrm{CaO}, \mathrm{SiO}_{2}$ and $\mathrm{Na}_{2} \mathrm{SO}_{4}$. The Cr-rich $\gamma$-phase initially reacted with $\mathrm{CaO}$ to form a molten $\mathrm{Ca}$ chromate, $\mathrm{Ca}$ aluminates and $\mathrm{Ni}$ and $\mathrm{Co}$ oxides. Once an external $\mathrm{Al}_{2} \mathrm{O}_{3}$ scale was established, it either reacted with $\mathrm{CaO}$ to form $\mathrm{Ca}$ aluminates, or dissolved in molten Na silicate. In both cases, this increased $\mathrm{Al}$ consumption, promoting $\mathrm{Al}_{2} \mathrm{O}_{3}$ failure for $\gamma$-rich alloys. These primary reaction modes were affected by the deposit compositions: $\mathrm{SiO}_{2}$ and $\mathrm{Al}_{2} \mathrm{O}_{3}$ were found to reduce the reactivity of $\mathrm{CaO}$, due to the formation of $\mathrm{Ca}$ aluminates 
and silicates in the deposit. Sodium sulfate, on the other hand, provided faster $\mathrm{Ca}$ transport and enhanced its reactivity toward the alloys. It also produced a locally high sulfur activity at the metal/oxide interface, and reduced scale adherence.

In service conditions, alkali metals may be present either as sulfates or as silicates, depending on the gas and deposit compositions. The present study shows that they can play an important role in the corrosion process either way, and even in successive ways. Indeed, changes in service conditions may lead to the deposition of $\mathrm{Na}_{2} \mathrm{SO}_{4}$, for instance, and its subsequent reaction with $\mathrm{SiO}_{2}$ to form a silicate, as was the case here.

Within the range of compositions studied, only deposits rich in $\mathrm{CaO}$ or those containing $\mathrm{Na}_{2} \mathrm{SO}_{4}$ and $\mathrm{SiO}_{2}$ proved potentially aggressive, and they mostly affected $\gamma$-rich, Cr-rich alloys. Both aspects are due to the nature of the primary reaction modes. In an alloy with relatively low $\mathrm{Al}$ and high $\mathrm{Cr}$, each reaction mode individually triggered internal oxidation, while with more $\mathrm{Al}$ and less $\mathrm{Cr}$, the reaction with $\mathrm{CaO}$ and the dissolution in Na silicate each consumed $\mathrm{Al}_{2} \mathrm{O}_{3}$, but its stability as an external scale was only compromised when the two modes were concurrent. Essentially, the deposits raised the minimum $\mathrm{Al}$ concentration required to maintain an external $\mathrm{Al}_{2} \mathrm{O}_{3}$ scale, to an extent increasing with increasing $\mathrm{Cr}$ level.

The present results indicate that with most deposits of realistic compositions, any $\mathrm{Al}_{2} \mathrm{O}_{3}$-forming alloy which would suffer internal oxidation is expected to repassivate eventually, in isothermal conditions. However, given the low adherence of the scales formed with the deposits and the enhanced $\mathrm{Al}$ depletion, thermal cycling would certainly have severe consequences, in particular if more deposit is applied periodically.

\section{Acknowledgements}

This work was supported by the Department of Energy through the University Turbine Systems Research (UTSR) Program run by the National Energy Technology Laboratory, award number DE-FE0007271, Seth Lawson, Project Manager. The authors thank Morgan Skapik and Kevin Glorius-Patrick for assistance in preparing the corrosion experiments, Gerald Meier and Nathaniel Bohna for useful discussions, and Xuan Liu and Zi-Kui Liu at the Pennsylvania State University for the phase equilibrium calculations.

\section{References}

[1] N. J. Simms, P. J. Kilgallon and J. E. Oakey, Fireside issues in advanced power generation systems, Energy Materials 2 (2007) pp. 154-160. doi: 10.1179/174892408X373509.

[2] G. Hammond, S. O. Akwe and S. Williams, Techno-economic appraisal of fossilfuelled power generation systems with carbon dioxide capture and storage, Energy 36 (2011) pp. 975-984. doi: 10.1016/j.energy.2010.12.012.

[3] B. Jenkins, L. Baxter, T. Miles and T. Miles, Combustion properties of biomass, Fuel Processing Technology 54 (1998) pp. 17-46. doi: 10.1016/S03783820(97)00059-3. 
[4] C. G. Levi, J. W. Hutchinson, M.-H. Vidal-Setif and C. A. Johnson, Environmental degradation of thermal-barrier coatings by molten deposits, MRS Bulletin 37 (2012) p. 932-941. doi: 10.1557/mrs.2012.230.

[5] J. P. Bons, J. Crosby, J. E. Wammack, B. I. Bentley and T. H. Fletcher, Highpressure turbine deposition in land-based gas turbines from various synfuels, Journal of Engineering for Gas Turbines and Power 129 (2005) p. 135-143. doi: 10.1115/1.2181181.

[6] B. M. White, R. W. Ames and P. Burke, Conditions in advanced turbines for igcc power plants with carbon capture, in Proceedings of the ASME Turbo Expo no. 55133 (2013).

[7] Clean Coal Technology Topical Report Number 24, NETL (US Department of Energy, August 2006).

[8] R. C. Reed, The Superalloys: Fundamentals and Applications. Cambridge University Press (2006).

[9] S. Bose, High Temperature Coatings. Burlington: Butterworth-Heinemann (2007).

[10] A. G. Evans, D. R. Mumm, J. W. Hutchinson, G. H. Meier and F. S. Pettit, Mechanisms controlling the durability of thermal barrier coatings, Progress in Materials Science 46 (2001) p. 505-553. doi: 10.1016/S0079-6425(00)00020-7.

[11] B. Gleeson, Thermal barrier coatings for aeroengine applications, Journal of Propulsion and Power 22 (2006) p. 375-383. doi: 10.2514/1.20734.

[12] A. G. Evans, D. R. Clarke and C. G. Levi, The influence of oxides on the performance of advanced gas turbines, Journal of the European Ceramic Society 28 (2008) p. 1405-1419. doi: 10.1016/j.jeurceramsoc.2007.12.023.

[13] D. R. Clarke, M. Oechsner and N. P. Padture, Thermal-barrier coatings for more efficient gas-turbine engines, MRS Bulletin 37 (2012) p. 891-902. doi: $10.1557 / \mathrm{mrs} .2012 .232$.

[14] R. Darolia, Thermal barrier coatings technology: critical review, progress update, remaining challenges and prospects, International Materials Reviews 58 (2013) p. 315-348. doi: 10.1179/1743280413y.0000000019.

[15] J. L. Smialek, F. A. Archer and R. G. Garlick, Turbine airfoil degradation in the persian gulf war, JOM 46 (1994) pp. 39-41. doi: 10.1007/BF03222663.

[16] M. P. Borom, C. A. Johnson and L. A. Peluso, Role of environmental deposits and operating surface temperature in spallation of air plasma sprayed thermal barrier coatings, Surface and Coatings Technology 86 (1996) p. 116-126. doi: 10.1016/s0257-8972(96)02994-5.

[17] C. Mercer, S. Faulhaber, A. Evans and R. Darolia, A delamination mechanism for thermal barrier coatings subject to calcium-magnesium-aluminosilicate (CMAS) infiltration, Acta Materialia 53 (2005) pp. 1029 - 1039. doi: 10.1016/j.actamat.2004.11.028.

[18] S. Kramer, J. Yang, C. G. Levi and C. A. Johnson, Thermochemical interaction of thermal barrier coatings with molten $\mathrm{CaO}-\mathrm{MgO}-\mathrm{Al}_{2} \mathrm{O}_{3}-\mathrm{SiO}_{2}$ (CMAS) deposits, Journal of the American Ceramic Society 89 (2006) p. 3167-3175. doi: 10.1111/j.1551-2916.2006.01209.x. 
[19] J. A. Goebel, F. S. Pettit and G. W. Goward, Mechanisms for hot corrosion of nickel-base alloys, Metallurgical Transactions 4 (1973) p. 261-278. doi: $10.1007 /$ bf02649626.

[20] J. Stringer, Hot corrosion of high-temperature alloys, Annual Review of Materials Science 7 (1977) pp. 477-509. doi: 10.1146/annurev.ms.07.080177.002401.

[21] R. A. Rapp, Chemistry and electrochemistry of the hot corrosion of metals, Corrosion 42 (1986) p. 568-577. doi: 10.5006/1.3583026.

[22] G. W. Goward, Low-temperature hot corrosion in gas-turbines: A review of causes and coatings therefor, Journal of Engineering for Gas Turbines and Power 108 (1986) p. 421-425. doi: 10.1115/1.3239921.

[23] N. Birks, G. H. Meier and F. S. Pettit, Introduction to the High Temperature Oxidation of Metals. Cambridge University Press 2nd ed. (2006).

[24] F. Pettit, Hot corrosion of metals and alloys, Oxidation of Metals 76 (2011) pp. 1-21. doi: 10.1007/s11085-011-9254-6.

[25] T. Gheno, G. H. Meier and B. Gleeson, High temperature reaction of MCrAlY coating compositions with $\mathrm{CaO}$ deposits, Oxidation of Metals 84 (2015) pp. 185-209. doi: 10.1007/s11085-015-9550-7.

[26] T. Gheno and B. Gleeson, On the reaction mechanism of MCrAlY alloys with oxide-sulfate deposits at $1100{ }^{\circ} \mathrm{C}$, Oxidation of Metals 86 (2016) pp. 385-406. doi: $10.1007 / \mathrm{s} 11085-016-9649-5$.

[27] T. Gheno and B. Gleeson, Kinetics of $\mathrm{Al}_{2} \mathrm{O}_{3}$-scale growth by oxidation and dissolution in molten silicate, Oxidation of Metals 87 (2017) pp. 527-539. doi: 10.1007/s11085-016-9686-0.

[28] U. R. Kattner, Construction of a thermodynamic database for Ni-base superalloys: A case study, in TMS: CALPHAD and Alloy Termodynamics The Minerals, Metals and Materials Society (2002).

[29] B. Sundman, B. Jansson and J. O. Andersson, The Thermo-Calc databank system, Calphad 9 (1985) p. 153-190. doi: 10.1016/0364-5916(85)90021-5.

[30] T. Gheno, X. L. Liu, G. Lindwall, Z.-K. Liu and B. Gleeson, Experimental study and thermodynamic modeling of the Al-Co-Cr-Ni system, Science and Technology of Advanced Materials 16 (2015) p. 055001. doi: 10.1088/14686996/16/5/055001.

[31] X. L. Liu, G. Lindwall, T. Gheno and Z.-K. Liu, Thermodynamic modeling of $\mathrm{Al}-\mathrm{Co}-\mathrm{Cr}, \mathrm{Al}-\mathrm{Co}-\mathrm{Ni}, \mathrm{Co}-\mathrm{Cr}-\mathrm{Ni}$ ternary systems towards a description for $\mathrm{Al}-$ Co-Cr-Ni, Calphad 52 (2016) pp. 125-142. doi: 10.1016/j.calphad.2015.12.007.

[32] Materials Preparation Center, Ames Laboratory, US DOE Basic Energy Sciences, Ames, IA, USA, available from: www.ameslab.gov/mpc.

[33] Evans Analytical Group, Liverpool, NY.

[34] V. K. Tolpygo and D. R. Clarke, Microstructural study of the theta-alpha transformation in alumina scales formed on nickel-aluminides, Materials at High Temperatures 17 (2000) p. 59-70. doi: 10.1179/mht.2000.011.

[35] Ftoxid 2010 database from factsage, phase diagram retrieved on http://www . crct.polymtl.ca/fact/documentation/, october 14, 2015. 
[36] C. S. Giggins and F. S. Pettit, Oxidation of Ni-Cr-Al alloys between $1000^{\circ}$ and $1200^{\circ} \mathrm{C}$, Journal of the Electrochemical Society 118 (1971) pp. 1782-1790. doi: $10.1149 / 1.2407837$.

[37] M. N. Task, B. Gleeson, F. S. Pettit and G. H. Meier, The effect of microstructure on the type II hot corrosion of Ni-base MCrAlY alloys, Oxidation of Metals 80 (2013) p. 125-146. doi: 10.1007/s11085-013-9405-z.

[38] T. Gheno, B.-C. Zhou, A. Ross, X. Liu, G. Lindwall, Z.-K. Liu and B. Gleeson, A thermodynamic approach to guide reactive element doping: Hf additions to NiCrAl, Oxidation of Metals 87 (2017) pp. 297-310. doi: 10.1007/s11085-0169706-0.

[39] A. Chyrkin, W. G. Sloof, R. Pillai, T. Galiullin, D. Gruener, L. Singheiser and W. J. Quadakkers, Modelling compositional changes in nickel base alloy 602 CA during high temperature oxidation, Materials at High Temperatures 32 (2015) p. 102-112. doi: 10.1179/0960340914z.00000000082.

[40] M. Schiek, L. Niewolak, W. Nowak, G. H. Meier, R. Vaßen and W. J. Quadakkers, Scale formation of alloy $602 \mathrm{CA}$ during isothermal oxidation at $800-1100{ }^{\circ} \mathrm{C}$ in different types of water vapor containing atmospheres, Oxidation of Metals 84 (2015) pp. 661-694. doi: 10.1007/s11085-015-9595-7.

[41] I. Barin, Thermochemical Data of Pure Substances. VCH second ed. (1993).

[42] D. Freyer and W. Voigt, Crystallization and phase stability of $\mathrm{CaSO}_{4}$ and $\mathrm{CaSO}_{4}$-based salts, Monatshefte für Chemie 134 (2003) pp. 693-719. doi: 10.1007/s00706-003-0590-3.

[43] P. Jose, D. Gupta and R. Rapp, Solubility of $\alpha-\mathrm{Al}_{2} \mathrm{O}_{3}$ in fused $\mathrm{Na}_{2} \mathrm{SO}_{4}$ at $1200 \mathrm{~K}$, Journal of the Electrochemical Society 132 (1985) pp. 735-737. doi: $10.1149 / 1.2113944$.

[44] M. G. Lawson, F. S. Pettit and J. R. Blachere, Hot corrosion of alumina, Journal of Materials Research 8 (1993) p. 1964-1971. doi: 10.1557/jmr.1993.1964.

[45] J. G. Smeggil, A. W. Funkenbusch and N. S. Bornstein, A relationship between indigenous impurity elements and protective oxide scale adherence characteristics, Metallurgical Transactions A 17 (1986) p. 923-932. doi: $10.1007 / \mathrm{bf02661258.}$

[46] J. L. Smialek, D. T. Jayne, J. C. Schaeffer and W. H. Murphy, Effects of hydrogen annealing, sulfur segregation and diffusion on the cyclic oxidation resistance of superalloys - a review, Thin Solid Films 253 (1994) p. 285-292. doi: 10.1016/0040-6090(94)90335-2.

[47] P. Y. Hou and J. Stringer, Oxide scale adhesion and impurity segregation at the scale/metal interface, Oxidation of Metals 38 (1992) pp. 323-345. doi: 10.1007/BF00665658.

[48] E. Levin, C. Robbins and H. McMurdie, Phase diagrams for ceramists vol. 1. The American Ceramic Society, Columbus, OH (1964).

[49] R. Melzer and W. Depmeier, A structural study of aluminate sodalite $\mathrm{Ca}_{8}\left[\mathrm{Al}_{12} \mathrm{O}_{24}\right]\left(\mathrm{CrO}_{4}\right)_{2}$ (CACr), Crystal Research and Technology 31 (1996) pp. 459-467. doi: 10.1002/crat.2170310409. 
[50] S. M. Antao, I. Hassan and J. B. Parise, Chromate aluminate sodalite, $\mathrm{Ca}_{8}\left[\mathrm{Al}_{12} \mathrm{O}_{24}\right]\left(\mathrm{CrO}_{4}\right)_{2}$ : Phase transitions and high-temperature structural evolution of the cubic phase, The Canadian Mineralogist 42 (2004) p. 1047. doi: 10.2113/gscanmin.42.4.1047. 